\title{
Cyclic porphyrin dimers as hosts for coordinating ligands
}

\author{
G VAIJAYANTHIMALA ${ }^{\mathrm{a}}$, V KRISHNAN ${ }^{\mathrm{a}, \mathrm{b}, *}$ and S K MANDAL ${ }^{\mathrm{a}}$ \\ ${ }^{a}$ Department of Inorganic and Physical Chemistry Indian Institute of Science, Bangalore 560012 \\ ${ }^{\mathrm{b}}$ Present address: Chemical Biology Unit of the Jawaharlal Nehru Centre for Advanced Scientific \\ Research, Indian Institute of Science Campus, Bangalore 560012 \\ e-mail: vkrish $@$ jnscar.ac.in
}

\begin{abstract}
Bicovalently linked tetraphenylporphyrins bearing dioxypentane groups at the opposite (transoid, $\mathrm{H}_{4} \mathrm{~A}$ ) and adjacent (cisoid, $\mathrm{H}_{4} \mathrm{~B}$ ) aryl groups have been synthesised. Protonation of the free-base porphyrins leads to fully protonated species $\mathrm{H}_{8} \mathrm{~A}^{4+} / \mathrm{H}_{8} \mathrm{~A}^{4+}$ accompanied by expansion of cavity size of the bisporphyrins. The electrochemical redox studies of these porphyrins and their Zinc(II) derivatives revealed that the first ring oxidation proceeds through a two-electron process while the second ring oxidation occurs at two distinct one-electron steps indicating unsymmetrical charge distribution in the oxidized intermediate. The axial ligation properties of the Zinc(Il) derivatives of $\mathrm{H}_{4} \mathrm{~A} / \mathrm{H}_{4} \mathrm{~B}$ with DABCO and PMDA investigated by spectroscopic and single crystal X-ray diffraction studies showed predominant existence of 1 : I complex. The $\mathrm{Zn}_{2} \mathrm{~A} \cdot \mathrm{DABCO}$ complex assumes an interesting eclipsed structure wherein $\mathrm{DABCO}$ is located inside the cavity between the two porphyrin planes with $\mathrm{Zn}-\mathrm{N}$ distances at 2.08 and $2.22 \AA$. The $\mathrm{Zn}$ atoms are pulled into the cavity due to coordination towards nitrogen atoms of DABCO and deviate from the mean porphyrin plane by $0.35 \AA$. The electrochemical redox potentials of the axially ligated metal derivatives are found to be sensitive function of the relative coordinating ability of the ligands and the conformation of the hosts.
\end{abstract}

Keywords. Crystal structure; cyclic porphyrin dimmers; host-guest complexes; solution conformation.

\section{Introduction}

There has been an increasing interest in the study of covalently linked bisporphyrins in view of their utility as models for the Reaction Centre complex of the photosynthetic system, as catalysts for $\mathrm{H}_{2} \mathrm{O}_{2}$ decomposition, ${ }^{1}$ mimicking certain enzyme functions ${ }^{2}$ and to evolve basic understanding for excitation energy and electron transfer reactions. ${ }^{3}$ The two porphyrin units linked through a single covalent linkage manifest in a multitude of conformers ${ }^{4}$ while bisporphyrins bearing more than one covalent linkage restrict the number of conformers that can be probed by different spectroscopies. The nature of the individual porphyrin units, the positions of the covalent attachment, the nature and the length of the linking groups play an important role in governing the properties of these porphyrins. Majority of the bisporphyrin systems reported were of octaalkylporphyrin derivatives. ${ }^{5}$ However, the syntheses of such systems involve multiple steps and lead to very low yields of

\footnotetext{
*For correspondence
}

the desired products. The synthetic procedure of these entities require the formation of amide ${ }^{6}$ or ester $^{7}$ linkages in the bridging units from the reaction of an acid chloride monomer with another monomer containing amine or alcohol chains under high dilution conditions. These dimers have unsubstituted meso positions which are susceptible to oxidation and hence render them unstable towards oxidising agents. ${ }^{8}$ On the other hand, meso-tetraphenylporphyrins are remarkable molecular candidates due to their ease of synthesis. A few cofacial bisporphyrin systems of meso-tetraphenylporphyrin have been reported with tetra-covalent linkage through phenyl groups. ${ }^{9}$ The first tetracovalently bridged cofacial bisporphyrin through a para-phenyl positions was reported by Kagan et $a l^{10}$ and through meta-phenyl positions by Karaman et al. ${ }^{11}$ Closely interspaced $\mathrm{R}-\left((\mathrm{TPP}) \mathrm{H}_{2}\right)_{2}$ are relatively unknown with the exception of a few bisporphyrins. ${ }^{9,12}$ The metal (II) derivatives of covalently linked porphyrin dimers have attracted a wide interest in the molecular recognition research. Hostguest complexation of cofacial bisporphyrins and cyclic tris and tetraporphyrins have been reported in the literature. ${ }^{13}$ 


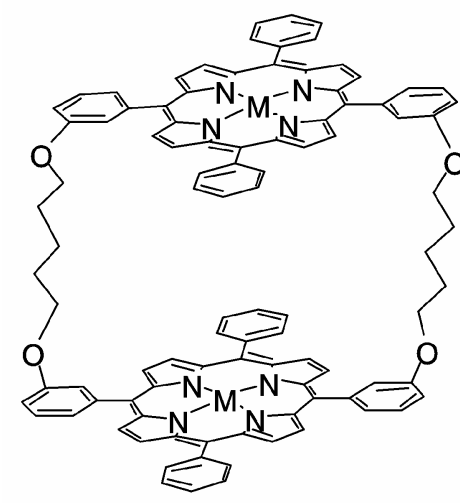

$\mathrm{Zn}_{2} \mathrm{~A}$

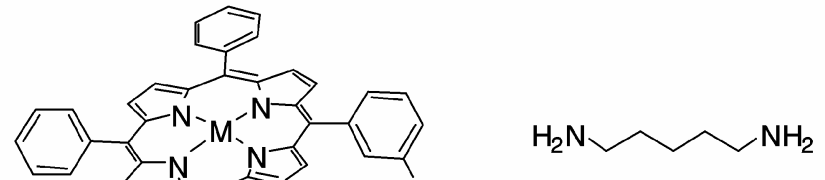

Pentamethylene Diamine<smiles>C1CN2CCN1CC2</smiles>

DABCO

Figure 1. Structures of bicovalently linked bisporphyrins $\mathrm{H}_{4} \mathrm{~A}$ and $\mathrm{H}_{4} \mathrm{~B}$. The axial ligands, 1,4diazobicyclo[2,2,2]octane, DABCO and 1,5-pentamethylenediamine are shown.

\section{Syntheses}

We present here a method for the facile synthesis of two bisporphyrins in different molecular geometries by using the meta-trans and meta-cis-dihydroxyphenyl derivatives of meso-tetraphenylporphyrins. The porphyrins that were linked through transphenyl rings with pentanedioxy chains leads to bisporphyrin trans- $\left(\mathrm{H}_{2} \mathrm{TPP}\right)_{2}, \mathrm{H}_{4} \mathrm{~A}$ and the one linked through cis-phenyl groups yielded a cis- $\left(\mathrm{H}_{2} \mathrm{TPP}\right)_{2}$, $\mathrm{H}_{4} \mathrm{~B}$ (figure 1). The ability of zinc derivatives of these porphyrins to bind bidentate ligands, 1,4diazobicyclo[2,2,2]octane(DABCO) and 1,5-pentamethylenediamine, (PMDA) inside the cavity is investigated and a structure of one of the complexes is reported here. The procedure adopted for the synthesis of bisporphyrins, $\mathrm{H}_{4} \mathrm{~A}$ and $\mathrm{H}_{4} \mathrm{~B}$, linked with pentyldioxy $(n=5)$ chain at high dilution conditions $\left(\sim 10^{-5} \mathrm{M}\right)$ resulted in fairly good yield $(\sim 12 \%)$ of the products. Attempts to synthesise bisporphyrins with short linkages $(n=2,3$ and 4$)$ resulted in the formation of open products with very low yields.

\section{Experimental}

Pyrrole (Fluka, Switzerland) was distilled over $\mathrm{KOH}$ pellets under reduced pressure. Benzaldehyde and meta/para-hydroxybenzaldehyde purchased from Aldrich were used without further purification. Pentamethylene dibromide procured from Aldrich Chemicals (USA) was used as received. The bidentate nitrogenous bases, DABCO (1,4-diazobicyclo[2,2,2] octane) PMDA (1,5-pentamethylenediamine) procured from Ranbaxy chemical company, India were of high purity are used as received.

The solvents were dried and distilled before use. The spectral and electrochemical redox measurements were carried out on instruments described elsewhere. ${ }^{24}$ Proper precautions were taken not to expose the solutions to bright light. Prior to spectral measurements, the solutions were purged with argon.

\subsection{Synthesis of bisporphyrins}

The synthetic strategy employed here is to couple the $5,10 / 15,15$-bis (3'-hydroxyphenyl)-15,20/10,20diphenylporphyrins with the corresponding preformed dipentamethylenebromide derivatives under high dilution reaction conditions.

3.1a 5,10/5,15-bis(3'-hydroxyphenyl)-15,20/10,20diphenylporphyrin: The cis/trans-dihydroxyphenyldiphenylporphyrins are synthesised by refluxing benzaldehyde $(2.08 \mathrm{~g}, 0.02 \mathrm{mmol})$, meta-hydroxybenzaldehyde $(2.45 \mathrm{~g}, 0.02 \mathrm{mmol})$ and pyrrole $(2.72 \mathrm{~g}$, $0.04 \mathrm{mmol})$ in propionic acid $\left(300 \mathrm{~cm}^{3}\right)$ for $45 \mathrm{~min}$. After the workup, the reaction mixture was subjected to TLC in $10: 1(\mathrm{v} / \mathrm{v}) \mathrm{CHCl}_{3}$ : acetone mixture. The six spots with relative $R_{f}$ values of $0.79,0.69,0.58$, $0.50,0.31$ and 0.12 corresponding to TPP (1), 5-(3'hydroxyphenyl)-10,15,20-triphenylporphyrin (2), 5,15bis(3'-hydroxyphenyl)-10,20-diphenyl porphyrin (3), 5,10-bis (3'-hydroxyphenyl)-15,20-diphenylporphyrin (4), 5,10,15-tris(3'-hydroxyphenyl)-20-phenylporphyrin (5) and 5,10, 15,20-tetrakis(3'-hydroxyphenyl)porphyrin (6) respectively were found. The 
separation of these porphyrins is accomplished by column chromatography employing a short column $(5 \times 60 \mathrm{~cm})$ containing activated silica gel. By careful change of the composition of eluting solvent mixture, $3(0.15 \mathrm{~g}, 2.4 \%), 4(0.23 \mathrm{~g}, 3.7 \%)$ and 5 $(0.45 \mathrm{~g}, 7 \cdot 1 \%)$ were separated using $1 \%, 2 \%$ and $3 \%$ of acetone in chloroform as solvent, respectively. The compounds are spectroscopically pure. ${ }^{1} \mathrm{H}$ NMR $\left(200 \mathrm{MHz}\right.$ in $\mathrm{CDCl}_{3}, \delta$ in ppm): $3 \delta 8.88(2 d, 8 \mathrm{H}$, $J=4.88 \mathrm{~Hz}, \mathrm{H}(3), 8.20$ ( $m, 4 \mathrm{H}, o$-unsub.phenyl $\mathrm{H})$, $7.77(m, 6 \mathrm{H}, 12, m$-unsub.phenyl $\mathrm{H}), 7.75-7.55(\mathrm{~m}$, $8 \mathrm{H}$, sub.phenyl $\mathrm{H}),-2.81(s, 2 \mathrm{H}$, imino $\mathrm{H}) ; 4 \delta 8.86$ $\left(2 d, 2 s, 8 \mathrm{H}, J=3.88 \mathrm{~Hz}, \mathrm{H}_{\beta}, 8.20(m, 8 \mathrm{H}\right.$, sub. phenyl $\mathrm{H}),-2.81(s, 2 \mathrm{H}$, imino $\mathrm{H}), 7.75(m, 6 \mathrm{H}, 12$, $m$-unsub.phenyl $\mathrm{H}), 7 \cdot 72-7.25(m, 8 \mathrm{H}$, sub.phenyl $\mathrm{H}),-2.81(s, 2 \mathrm{H}$, imino $\mathrm{H}) ; 5 \delta 8.91\left(m, 8 \mathrm{H}, \mathrm{H}_{\beta}\right)$, $8.22(m, 2 \mathrm{H}, o$-unsub.phenyl $\mathrm{H}), 7.76(m, 3 \mathrm{H}, p, m-$ unsub.phenyl $\mathrm{H}), 7 \cdot 74-7 \cdot 30(\mathrm{~m}, 12 \mathrm{H}$, sub.phenyl $\mathrm{H})$, $-2.77(s, 2 \mathrm{H}$, imino $\mathrm{H})$.

$3.1 \mathrm{~b} \quad 5,10 / 5,15-b i s(3 '-(1-b r o m o p e n t y l o x y)$ phenyl)-l5, 20/10,20-diphenylporphyrin: The functionalised free-base porphyrin, $m$-cis/trans-dihydroxy porphyrin $(0.2 \mathrm{~g}, 0.3 \mathrm{mmol})$ was dissolved in $100 \mathrm{~cm}^{3}$ of dry distilled acetone containing $1 \mathrm{~g}$ of anhydrous $\mathrm{K}_{2} \mathrm{CO}_{3}$. To this $1 \mathrm{~cm}^{3}$ of 1,5-dibromopentane $\left[\mathrm{Br}-\left(\mathrm{CH}_{2}\right)_{5}-\mathrm{Br}\right]$ was added and the reaction mixture was refluxed for a period of $48 \mathrm{~h}$. Subsequent to the removal of solvent and washing the residue with water, it was dissolved in a minimum amount of $\mathrm{CHCl}_{3}$ and chromatographed on a neutral alumina column using $\mathrm{CHCl}_{3}$ as the eluent. The title compound was eluted as a first band $(0 \cdot 26 \mathrm{~g}, 90 \%) .{ }^{1} \mathrm{H}$ NMR $(200 \mathrm{MHz}$, in $\mathrm{CDCl}_{3}, \quad \delta$ in ppm) m-trans- $\mathrm{H}_{2} \mathrm{TPP}\left(\mathrm{O}-(1) \mathrm{CH}_{2}-\right.$ (2) $\left.\mathrm{CH}_{2}-(3) \mathrm{CH}_{2}(4) \mathrm{CH}_{2}-(5) \mathrm{CH}_{2}-\mathrm{Br}\right)_{2}: 8.82-8.90$ (2d, $\left.J=4.85 \mathrm{~Hz}, \quad 8 \mathrm{H}, \quad \mathrm{H}_{\beta}\right), \quad 8.19-8.23 \quad(m, \quad 4 \mathrm{H}, \quad$ Qunsub.phenyl-H), 7.77 ( $m, 6 \mathrm{H}, m, 12$-unsub.phenyl $\mathrm{H}), \quad 7.66-7.28(m, 8 \mathrm{H}$, subs.phenyl-H $), 4.15(t$, $\left.J=6.20 \mathrm{~Hz}, 4 \mathrm{H},-\mathrm{OCH}_{2}-\right), 3.43(t, J=6.66 \mathrm{~Hz}, 4 \mathrm{H}$, $\left.-\mathrm{CH}_{2} \mathrm{Br}-\right), 1.91\left(m, 8 \mathrm{H},(2,4) \mathrm{CH}_{2}-\right), 1.67(m, 4 \mathrm{H},-$ (3) $\left.\mathrm{CH}_{2}-\right),-2.79(s, 2 \mathrm{H}$, imino $\mathrm{H}) ; m-c i s-\mathrm{H}_{2} \mathrm{TPP}\left(\mathrm{O}_{-}\right.$ (1) $\left.\mathrm{CH}-(2) \mathrm{CH}_{2}-(3) \mathrm{CH}_{2}-(4) \mathrm{CH}_{2}(5) \mathrm{CH}_{2}-\mathrm{Br}\right)_{2}: 8.82-8.90$ $\left(2 d, J=4.85 \mathrm{~Hz}, 8 \mathrm{H}, \mathrm{H}_{\beta}\right), 8 \cdot 19-8.23(m, 4 \mathrm{H}, o-$ unsub.phenyl $\mathrm{H}), 7.77(\mathrm{~m}, 6 \mathrm{H}, m, 12$-unsub.phenyl $\mathrm{H}), 7.68-7.58,7.33-7.28(\mathrm{~m}, 8 \mathrm{H}$, subs.phenyl-H), $4.14 \quad\left(t, \quad J=6.16 \mathrm{~Hz}, \quad 4 \mathrm{H}, \quad-\mathrm{OCH}_{2}-\right), \quad 3.42 \quad(t$, $\left.J=6.65 \mathrm{~Hz}, 4 \mathrm{H},-\mathrm{CH}_{2} \mathrm{Br}\right), 1.91\left(m, 8 \mathrm{H},-(2,4) \mathrm{CH}_{2}-\right)$, $1.67\left(m, 4 \mathrm{H},-(3) \mathrm{CH}_{2}-\right),-2.79(s, 2 \mathrm{H}$, imino $\mathrm{H})$.

3.1c Bi-covalently linked free-base bisporphyrins: In a typical bisporphyrin synthesis, m-cis/trans-
$\mathrm{H}_{2}(\mathrm{TPP})\left(\mathrm{O}\left(\mathrm{CH}_{2}\right)_{5} \mathrm{Br}\right)_{2}(0.12 \mathrm{~g}, 0.13 \mathrm{mmol})$ and $m$ cis/trans $-\mathrm{H}_{2}(\mathrm{TPP})(\mathrm{OH})_{2} \quad(0.08 \mathrm{~g}, \quad 0.13 \mathrm{mmol})$ were dissolved in dry DMF $\left(100 \mathrm{~cm}^{3}\right)$. This solution was added slowly to a stirring solution of DMF $\left(1 \mathrm{dm}^{3}\right)$ containing $\mathrm{K}_{2} \mathrm{CO}_{3}(\mathrm{lg})$ over a period of $12 \mathrm{~h}$. The reaction mixture was stirred for a further period of $48 \mathrm{~h}$. The reaction mixture was filtered and the solvent, DMF was removed under reduced pressure to obtain the purple solid. After the work up, the unreacted porphyrin dibromide was removed as a first band from column chromatography (silica gel) and the second band was subjected to preparative TLC on a $0.05 \times 20 \times 20 \mathrm{~cm}$ silica gel plate using toluene as the eluent. TLC showed a single band when the starting material used was m-trans-dihydroxyporphyrin and it was collected to give bisporphyrin, $\mathrm{H}_{4} \mathrm{~A}(0.018 \mathrm{~g}, 10 \%)$. Several bands were observed on TLC when the starting material employed was $m$ cis-dihydroxyporphyrin derivatives. Each band was collected separately and characterised by ${ }^{1} \mathrm{H}$ NMR. The first non-polar band was collected to give the bisporphyrin, $\mathrm{H}_{4} \mathrm{~B}(0.022 \mathrm{~g}, 12 \%)$. The yields were based on the amount of dihydroxyphenylporphyrins employed in the reaction. FAB MASS showed a molecular ion peak $(\mathrm{m} / \mathrm{z})$ at $1431.00(\mathrm{M}+1)^{ \pm}$for $\mathrm{H}_{4} \mathrm{~A}$ or $\mathrm{H}_{4} \mathrm{~B}$. (calc. $\mathrm{C}_{98} \mathrm{H}_{76} \mathrm{O}_{4} \mathrm{~N}_{8}\left(\mathrm{M}^{ \pm}\right)=1429.71$ ). The $R_{f}$ values for $\mathrm{H}_{4} \mathrm{~A}$ and $\mathrm{H}_{4} \mathrm{~B}$ are 0.29 and 0.23 (toluene: Pet.ether, $2: 1, \mathrm{v} / \mathrm{v})$, respectively.

The zinc(II) derivatives of the bisporphyrins were prepared using the appropriate metal acetate as the metal carrier by procedures described in literature. The metallation of the bisporphyrins was followed by optical spectroscopy to ensure that both the porphyrin units are metallated. The yields were 90\% based on the amount of free-base bisporphyrins used.

\subsection{Methods}

The protonation of the bisporphyrins was followed by optical and ${ }^{\mathrm{I}} \mathrm{H}$ NMR spectroscopic methods. Solution $\left(0.5 \mathrm{~cm}^{3}\right)$ in $\mathrm{CDCl}_{3}$ with porphyrin of known concentration $\left(10^{-2} \mathrm{M}\right)$ were titrated directly in an NMR tube by successive addition of TFA $(0.01-$ $10 \mathrm{M}$ ) using a microliter syringe. The total volume change over a complete protonation sequence was negligible. After each addition, the solution was mixed and spectra were measured over the range -5 to $+10 \delta$.

The equilibrium constants, $\mathrm{K}$ for the complexation of zinc(II) derivatives of bisporphyrins with bidendate ligands, DABCO and PMDA have been 
determined using optical absorption method at 298 K. All measurements were made using 1,2dichloroethane as the solvent. The concentration of the bisporphyrins were maintained at $1 \times 10^{-5} \mathrm{M}$, while the concentration of the base was varied from $1 \times 10^{-5} \mathrm{M}$ to $1 \times 10^{-1} \mathrm{M}$. The equilibrium constants, $\mathrm{K}$ were evaluated from the change in absorbance of the $\mathrm{Q}$ transitions of zinc(II) bisporphyrins on increasing addition of base. Hill plots ${ }^{25}$ were constructed using standard least square fit programs to determine stoichiometry of the complex and to evaluate the binding constant, $\mathrm{K}$. The ${ }^{1} \mathrm{H}$ NMR spectral titration was performed on increasing addition of base to a bisporphyrin $(1 \mathrm{mM})$ solution in $\mathrm{CDCl}_{3}$.

3.2a X-ray crystallographic data: Single crystals of this host-guest complex, $\mathrm{Zn}_{2} \mathrm{~A}-\mathrm{DABCO} . \mathrm{8C}_{2} \mathrm{H}_{4} \mathrm{Cl}_{2}$. $\mathrm{H}_{2} \mathrm{O}$ was obtained by the slow evaporation of a $\mathrm{Zn}_{2} \mathrm{~A}$ : DABCO (1:1.20) dichloroethane solution at ambient temperature.

3.2b Crystal data: $\mathrm{C}_{120} \mathrm{Hl}_{18} \mathrm{~N}_{10} \mathrm{Zn}_{2} \mathrm{Cl}_{2}, \mathrm{M}=2478.32$, monoclinic, space group $P 2{ }_{1} / c, a=14.103(8) \AA$, $b=18.673(9) \AA, c=23.815(8) \AA, \beta=107.11(4)^{\circ}$ $\left(\mathrm{V}=5994(5) \AA^{3}\right.$ (by least-squares refinement of 25 reflections), $\lambda=0.7107 \AA, Z=2, D_{c}=1.37 \mathrm{~g} \mathrm{~cm}^{3}$, red diamond shaped crystals, crystal dimensions $0.42 \times 0.41 \times 0.35 \mathrm{~mm}, \mu\left(\mathrm{MoK}_{\alpha}\right)=8.24 \mathrm{~cm}^{-1}$.

3.2c Data collection and processing: A CAD4 diffractometer; graphite-monochromated $\mathrm{MoK}_{\alpha}$ radiation; $2 \theta$ scan mode; range $4^{\circ}-40^{\circ} ; 5493$ unique reflections; $R_{\text {merge }}=(0.0914) ; 3782$ observed reflections with $I>30(1)\left[w=1 \cdot 0 / \sigma^{2}\left(F_{o}\right)\right] ; 40 \%$ crystal decay.

$3.2 \mathrm{~d}$ Structure analysis and refinement: The structure was solved by direct methods using SHELXS$86^{26}$ and the remaining atoms were located from difference Fourier maps. All hydrogen atoms were wither located or put at the calculated positions with an isotropic thermal parameter of $0 \cdot 1\left(\AA^{2}\right)$ and were not refined. Carbon atoms of the DABCO were found to be positionally disordered and six sites were refined with a site occupancy factor (sof) of $0 \cdot 5$. Chlorine atoms of one of the dichloroethane molecules also were found to be positionally disordered and the four sites were refined with a sof of 0.5. Full matrix leastsquares refinement using SHELX-76 program ${ }^{27}$ converged $R=0.0914$ and $R_{w}=0.0965\left[2 \theta=4-40^{\circ}, I>3 \sigma(I)\right]$ and $w=1.0 / \sigma^{2}\left(F_{o}\right)$.
Additional material available from the Cambridge Crystallographic Data Centre comprises thermal parameters and remaining bond lengths and bond angles.

\section{Results and discussion}

The products were identified by FAB Mass and ${ }^{1} \mathrm{H}$ NMR spectroscopic methods. The ${ }^{1} \mathrm{H}$ NMR spectra of bisporphyrins, $\mathrm{H}_{4} \mathrm{~A}$ and $\mathrm{H}_{4} \mathrm{~B}$ are highly characteristic and furnish information on the possible conformations in solution (figure 2). The proton resonances of $\mathrm{H}_{4} \mathrm{~A}$ and $\mathrm{H}_{4} \mathrm{~B}$ occur in a shielded region relative to the monomeric $\mathrm{H}_{2}$ TPP indicative of the presence of ring current effect induced by the proximal disposition of two porphyrin units. ${ }^{9,14}$ The imino protons of the free-base porphyrin, $\mathrm{H}_{4} \mathrm{~A}$ resonate as a singlet at $-3.14 \mathrm{ppm}$ shifted upfield relative to the resonances of inner imino protons of monomeric $\mathrm{H}_{2}$ TPP $(\sim 2.71 \mathrm{ppm})$ while a multiplet ( -2.94 ppm) was observed for $\mathrm{H}_{4} \mathrm{~B}$ relative to that of monomeric porphyrin suggest co-facial arrangement of the porphyrin units. Interestingly, the multiplet resonance around $-2.94 \mathrm{ppm}$ observed for $\mathrm{H}_{4} \mathrm{~B}$ is resolved to two broad singlets $(-3.00$ and $-3.11 \mathrm{ppm})$, on lowering the temperature $\left(-45^{\circ} \mathrm{C}\right)$ while under similar conditions, the singlet resonance observed for $\mathrm{H}_{4} \mathrm{~A}$ remain unaffected. The occurrence of two singlet resonances arises from chemical non-equivalence of the imino protons in $\mathrm{H}_{4} \mathrm{~B}$ due to the preferred location of the protons in each of the porphyrins unit. It may be pointed out here that in $\mathrm{H}_{4} \mathrm{~B}$, the covalent linkages at the adjacent aryl groups make two of the pyrrole rings in each of the porphyrin unit distinct from the others. ${ }^{15}$ The single resonance observed for $\mathrm{H}_{4} \mathrm{~A}$ indicates that both the imino protons are equivalent. The pyrrolic protons of $\mathrm{H}_{4} \mathrm{~A}$ resonate as two distinct doublets at 8.69 and $8.62 \mathrm{ppm}$ while a multiplet resonance around $8.81 \mathrm{ppm}$ was observed for $\mathrm{H}_{4} \mathrm{~B}$. The appearance of two doublets in $\mathrm{H}_{4} \mathrm{~B}$ is similar to those observed for transdiaminophenyldiphenylporphyrin reported by Sun et $a l^{16}$. The multiplet resonance seen in $\mathrm{H}_{4} \mathrm{~B}$ arise essentially from the different conformations of $\mathrm{H}_{4} B$ due to the presence of flexible covalent linkages at the adjacent aryl groups and due to the non-equivalence of $\beta$-pyrrole protons. Interestingly, lowering of temperature results in absence of the multiplet resonance and appearance of two doublets for $\beta$ pyrrole protons, signaling the preferred conformation of $\mathrm{H}_{4} \mathrm{~B}$. It is noteworthy that under similar con- 
(a)

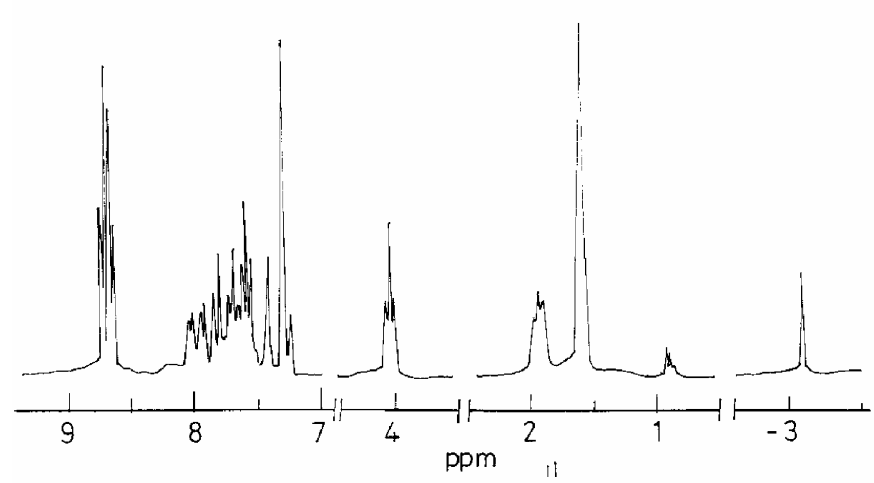

(b)

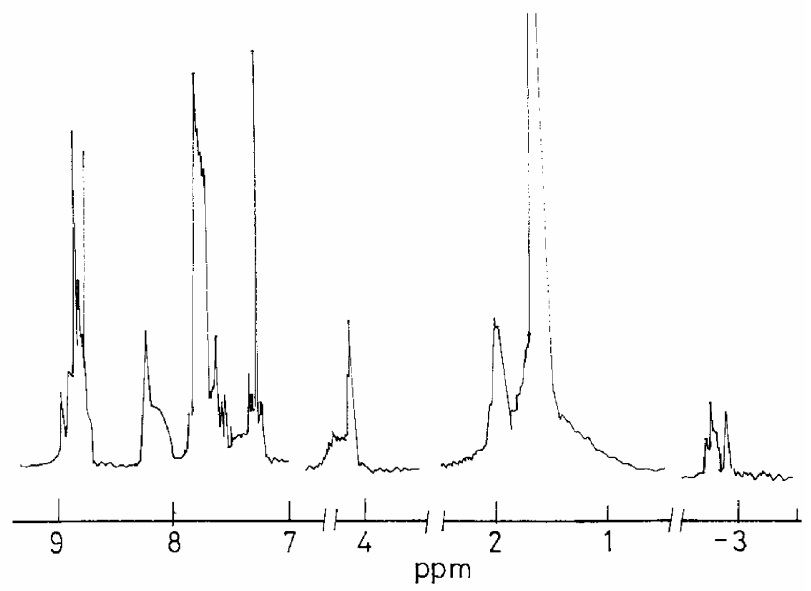

Figure 2. The ${ }^{1} \mathrm{H}$ NMR spectra of (a) $\mathrm{H}_{4} \mathrm{~A}$ and (b) $\mathrm{H}_{4} \mathrm{~B}$ inCDCl $\mathrm{Cl}_{3}$ at $298 \mathrm{~K}$.

ditions, the pyrrole proton resonance of $\mathrm{H}_{4} \mathrm{~A}$ are not significantly affected, indicating that co-facial conformation persists at low temperature. The proton resonances of the meso-aryl groups of $\mathrm{H}_{4} \mathrm{~A}$ and $\mathrm{H}_{4} \mathrm{~B}$ are very instructive in arriving at the different orientational features. The four ortho protons $\left(2^{\prime}\right)$ in $\mathrm{H}_{4} \mathrm{~A}$ which are projecting inside the cavity resonate at $7.39 \mathrm{ppm}$ while the other four ortho protons (6') resonate as a multiplet at $7.80 \mathrm{ppm}$. The protons $(2$ and 6) of the unsubstituted aryl groups resonate as a multiplet centered around $8.02 \mathrm{ppm}$ and $7.98 \mathrm{ppm}$ respectively. The shielding effect experienced by the protons of the substituted meso-aryl groups $\left(2^{\prime}\right)$ indicates the influence of ring current arising from the face-to-face orientation of the porphyrin units. ${ }^{11,17}$ The resonance of phenyl protons of $\mathrm{H}_{4} \mathrm{~B}$, however, appear as a complex multiplet and hence no detailed assignments are made. The assignment of the proton resonance of the bridging groups is largely aided by the spectra of the 2,5-dibromopentane $(a)$ and the precursor complex, 5,10/5,15bis[3'-(1-bromopentoxyphenyl]-15,20/10,20-diphenylporphyrin $(b)$. The bisporphyrins, $\mathrm{H}_{4} \mathrm{~A}$ and $\mathrm{H}_{4} \mathrm{~B}$ exhibit resonances of the bridging protons at $4.04 \mathrm{ppm}(t)$ and at $1.90 \mathrm{ppm}(\mathrm{m})$ corresponding to $\mathrm{OCH}_{2}^{-}$and $\left(-\mathrm{CH}_{2}-\mathrm{CH}_{2}-\mathrm{CH}_{2}-\right)$ protons. The observed proton resonance spectral results are indicative of the face to face conformation of porphyrin rings in $\mathrm{H}_{4} \mathrm{~A}$ and predominantly endo-cis orientation of the porphyrin rings in $\mathrm{H}_{4} \mathrm{~B}$. The ${ }^{1} \mathrm{H}$ NMR spectra of the zinc(II) derivatives of $\mathrm{H}_{4} \mathrm{~A}$ and $\mathrm{H}_{4} \mathrm{~B}$ exhibit resonances similar to those of the multiplet structure of free-base indicating no major conformational change on metallation.

\subsection{Protonation studies}

Interesting results are obtained on protonation of these porphyrins. Typical spectra of acid titration of the bisporphyrins, $\mathrm{H}_{4} \mathrm{~A}$ and $\mathrm{H}_{4} \mathrm{~B}$ are shown in figures 3 and 4 respectively. It is found that addition of acid to the bisporphyrins results in the complete disappearance of the ring current induced shifts of proton resonances of $\beta$-pyrrole, imino and bridging methylene groups. The ${ }^{1} \mathrm{H}$ NMR spectra of $\mathrm{H}_{4} \mathrm{~A}$ and $\mathrm{H}_{4} \mathrm{~B}$ in less than four equivalents of acid $(0.03 \mathrm{M})$ consists of resonances that can be ascribed to both free and fully protonated species, $\mathrm{H}_{8} \mathrm{P}^{4+}$ (figures $3 \mathrm{~b}$ and $4 \mathrm{~b}$ ). The absence of resonances at intermediate positions is ascribed to the absence of partially protonated intermediates, similar to that found for the $\mathrm{H}_{2} \mathrm{TPP}$ and (DMA) ${ }_{4} \mathrm{PH}_{2}$ [tetrakis ( $p$-dimethylaminophenyl)porphyrin]. The intensity ratio of resonances of $\mathrm{H}_{8} \mathrm{P}^{4+}$ and $\mathrm{H}_{4} \mathrm{P}$ increases with increase in concentration of the acid. The formation of fully protonated species is complete on addition of 4 equivalents of acid $(0.05 \mathrm{M})$. The internal $\mathrm{N}-\mathrm{H}$ proton resonance at $3.14 \mathrm{ppm}$ in $\mathrm{H}_{4} \mathrm{~A}$ is shifted downfield to $0.18 \mathrm{ppm}$ upon formation of $\mathrm{H}_{8} \mathrm{P}^{4+}$. As the concentration of TFA is increased beyond $0.05 \mathrm{M}$, the $\mathrm{N}-\mathrm{H}$ resonance gradually moves towards upfield and in TFA solvent, this signal appears as a singlet at $-2.25 \mathrm{ppm}$. The proton resonances that are followed are those of only inner imino nitrogens. Occasionally, it is difficult to locate the $\mathrm{N}-\mathrm{H}$ protons on addition of acid (figure $2 \mathrm{~b}$ ). The position of the resonance has been resolved by deutration experiments. Substantial changes are observed in the chemical shifts of $-\mathrm{OCH}_{2}, \beta$-pyrrole and aromatic protons as the tetra- 
protonation takes place. The resonance of $\beta$-pyrrole protons moves upfield from $8.64 \mathrm{ppm}$ by $0.2 \mathrm{ppm}$ and that of $-\mathrm{OCH}_{2}$ protons shifted downfield by $0 \cdot 3 \mathrm{ppm}$. These shifts in the proton resonances are in the directions to be expected if the aromatic ring current decreases on protonation. As the TFA concentration is increased beyond that necessary to form $\mathrm{H}_{8} \mathrm{P}^{4+}$, these signals again move continuously in opposite direction (figures $3 \mathrm{c}-\mathrm{f}$ ) with the resonances of $\mathrm{H}_{\beta}$ shifted downfield by $0.1 \mathrm{ppm}$ and that of $\mathrm{N}-\mathrm{H}$ protons shifted upfield by $2.10 \mathrm{ppm}$. The meso-aryl proton resonances are broadened signifi-

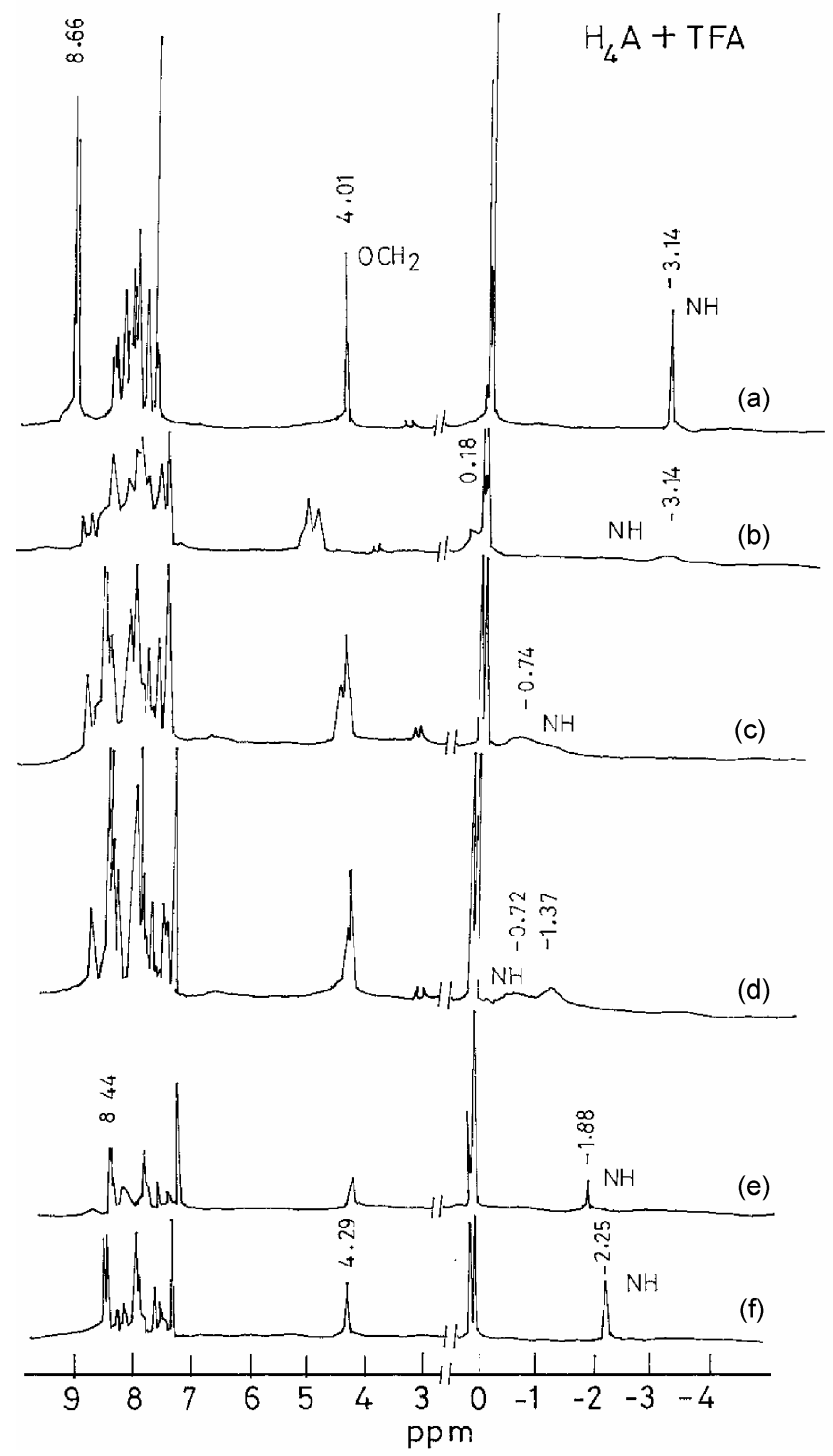

Figure 3. The chemical shifts of proton resonances of $\mathrm{H}_{4} \mathrm{~A}$ in $\mathrm{CDCl}_{3}$ at $298 \mathrm{~K}$ with increasing addition of TFA. The concentrations of TFA added are: (a) $0.0 \mathrm{M}$; (b) $0.03 \mathrm{M}$; (c), 0.07 M; (d) 0.1 M; (e) $0.2 \mathrm{M}$; (f), neat TFA. cantly, eventually with the disappearance of multiplet structure in TFA solution. The direction of proton resonance shifts on protonation of $\mathrm{H}_{4} \mathrm{~B}$ follows the same patterns as that observed for $\mathrm{H}_{4} \mathrm{~A}$, however, the magnitude of the shifts of the resonances is quite different. Upon formation of $\mathrm{H}_{8} \mathrm{~B}^{4+}$, the imino proton resonance at $-2.91 \mathrm{ppm}$ in $\mathrm{H}_{4} \mathrm{~B}$ shifted downfield to $0.32 \mathrm{ppm}$ at 4 equiv of acid $(0.05 \mathrm{M})$ (figure $3 c)$. On increasing the concentration of TFA, the signal moves gradually upfield (figures $3 \mathrm{~d}-\mathrm{f}$ ), and appears as a complex multiplet around $-1.60 \mathrm{ppm}$ in TFA solvent (figure 3g). The complex multiplicity and downfield shift of the resonances of imino protons of $\mathrm{H}_{8} \mathrm{~B}^{4+}$, relative to that of $\mathrm{H}_{8} \mathrm{~A}^{4+}$ reveals that

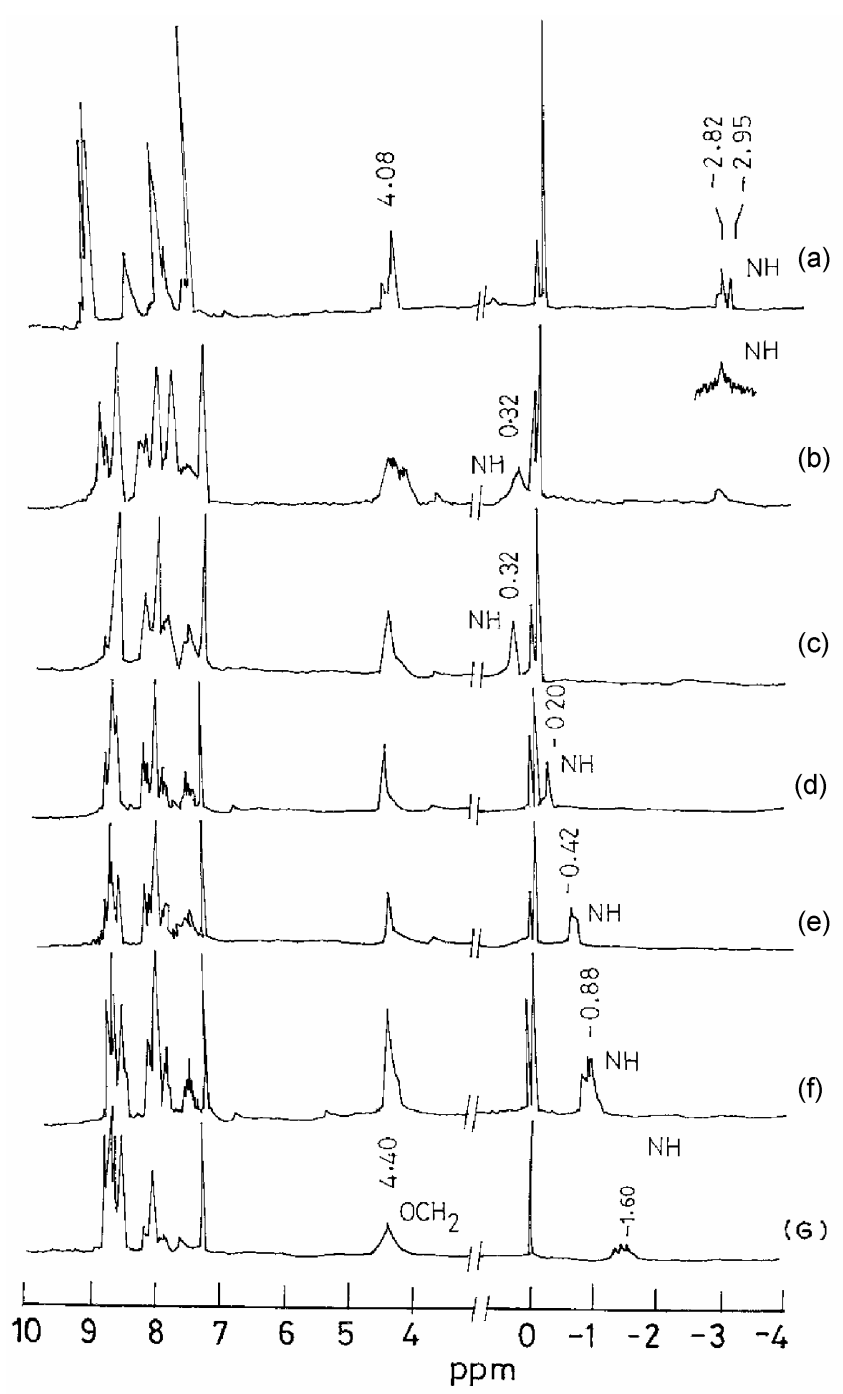

Figure 4. The chemical shifts of proton resonances of $\mathrm{H}_{4} \mathrm{~B}$ in $\mathrm{CDCl}_{3}$ at $298 \mathrm{~K}$ with increasing addition of TFA. The concentrations of TFA added are: (a), $0.0 \mathrm{M}$; (b) 0.03 M; (c) $0.05 \mathrm{M}$; (d) $0.07 \mathrm{M}$; (e) $0.1 \mathrm{M}$; (f) $0.2 \mathrm{M}$; (g) neat TFA. 
Table 1. Optical and electrochemical redox data on free-base bisporphyrins and their zinc(II) derivatives in $\mathrm{C}_{2} \mathrm{H}_{4} \mathrm{Cl}_{2}$ at $298 \mathrm{~K}$.

\begin{tabular}{|c|c|c|c|c|c|c|}
\hline Compound & $\lambda_{\mathrm{abs}}(\mathrm{nm})$ & $\lambda_{\mathrm{em}}{ }^{\mathrm{a}}(\mathrm{nm})$ & $\begin{array}{c}\mathrm{P} \rightarrow \mathrm{P}^{+} \\
(\mathrm{mv})\end{array}$ & $\begin{array}{c}\mathrm{P}^{+\cdot} \rightarrow \mathrm{P}^{2+} \\
(\mathrm{mv})\end{array}$ & $\begin{array}{l}P \rightarrow P^{-*} \\
\quad(\mathrm{mv})\end{array}$ & $\begin{array}{c}\mathrm{P}^{-\cdot} \rightarrow \mathrm{P}^{2-} \\
(\mathrm{mv})\end{array}$ \\
\hline $\mathrm{H}_{4} \mathrm{~A}$ & $\begin{array}{l}415.8(5.66) \\
514.7(4.31) \\
549.9(3.94) \\
589.6(3.81) \\
645.6(3.67)\end{array}$ & $\begin{array}{c}648 \\
714 \\
(0 \cdot 072)\end{array}$ & +490 & $\begin{array}{r}+850 \\
+1070\end{array}$ & -1650 & c \\
\hline $\mathrm{H}_{4} \mathrm{~B}$ & $\begin{array}{l}418 \cdot 1(5 \cdot 75) \\
514.6(4 \cdot 39) \\
549.3(4 \cdot 00) \\
589.0(3 \cdot 85) \\
644.0(3.70)\end{array}$ & $\begin{array}{c}648 \\
714 \\
(0 \cdot 088)\end{array}$ & +510 & $\begin{array}{r}+820 \\
+1020\end{array}$ & -1780 & -2060 \\
\hline $\mathrm{Zn}_{2} \mathrm{~A}$ & $\begin{array}{l}415.7(5.81) \\
549.3(4.42) \\
588.6(3.71)\end{array}$ & $\begin{array}{c}601 \\
650 \\
(0 \cdot 002)\end{array}$ & +310 & +650 & 2030 & c \\
\hline $\mathrm{Zn}_{2} \mathrm{~B}$ & $\begin{array}{l}420 \cdot 0(5 \cdot 60) \\
549 \cdot 2(4 \cdot 30) \\
589 \cdot 0(3.69)\end{array}$ & $\begin{array}{c}598 \\
645 \\
(0.018)\end{array}$ & +260 & +600 & c & c \\
\hline
\end{tabular}

${ }^{\mathrm{a}} \lambda_{\text {ex }}=420 \mathrm{~nm}$. The quantum yields $(q)$ are with reference to $\mathrm{H}_{2}$ TPP and ZnTPP in benzene respectively. ${ }^{b}$ The redox potentials are with reference to $\mathrm{Fc}^{+} / \mathrm{Fc}$ in $\mathrm{C}_{2} \mathrm{H}_{4} \mathrm{Cl}_{2}$.

${ }^{\mathrm{c}}$ The potentials are not observed

the bisporphyrin opens up to fully extended form due to electrostatic repulsion. This movement causes the porphyrin protons to be out of the ring current effect induced by the other unit of the bisporphyrin suggesting expansion of the cavity caused by repulsion due to protonation. This makes all the four $\mathrm{N}-\mathrm{H}$ protons in each unit chemically non-equivalent in $\left(\mathrm{H}_{8} \mathrm{~B}^{4+}\right)$ and giving rise to a complex multiplet in TFA. These changes in resonances are connected with distortion of planar porphyrin $\pi$-system. ${ }^{17}$

The electronic absorption spectra of $\mathrm{H}_{4} \mathrm{~A}$ and $\mathrm{H}_{4} \mathrm{~B}$ exhibit characteristic etio type of spectra with the appearance of an intense Soret band (B) in the region $410-420 \mathrm{~nm}$ followed by four Q bands (table 1). There is a marginal blue shift of the Soret band $\left(250 \mathrm{~cm}^{-1}\right)$ in $\mathrm{H}_{4} \mathrm{~A}$ relative to that observed for $\mathrm{H}_{2}$ TPP (monomer) and a general increase in oscillator strength of these bands are suggestive of weak $\pi-\pi$ interaction between the porphyrin planes. The fluorescence spectra of $\mathrm{H}_{4} \mathrm{~A}$ and $\mathrm{H}_{4} \mathrm{~B}$ and their zinc(II) derivatives exhibit two emissions corresponding to $\mathbf{Q}_{(0,0)}$ and $\mathrm{Q}_{(0,1)}$ bands (figure 5). It is seen that the free-base porphyrins and zinc(II) derivatives exhibit fluorescence with large decrease in intensity and quantum yield relative to that of corresponding monomers. ${ }^{18}$ The free-base bisporphyrins $\mathrm{H}_{4} \mathrm{~A}$ and $\mathrm{H}_{4} \mathrm{~B}$ exhibit $35 \%$ and $20 \%$ reduction in the emission intensity respectively, relative to that observed for monomeric $\mathrm{H}_{2}$ TPP. The zinc(II) dimers show a sub- stantial increase in quenching relative to that observed for the free-base dimers indicating that the inter-ring interaction is enhanced on metallation.

\subsection{Redox chemistry}

The electrochemical redox studies of $\mathrm{H}_{4} \mathrm{~A}, \mathrm{H}_{4} \mathrm{~B}$ and their zinc(II) derivatives reveal the manner in which individual porphyrin rings respond to oxidation/ reduction reactions. All the potentials are reversible and involve one electron process unless otherwise stated. The free-base bisporphyrins exhibit twoelectron first ring oxidation process leading to the formation of $\mathrm{H}_{2} \mathrm{P}^{+\cdot}-\mathrm{H}_{2} \mathrm{P}^{+\cdot}$ and they occur at less positive potential relative to that found for $\mathrm{H}_{2}$ TPP. The second ring oxidation occurs in two successive oneelectron steps resulting in $\mathrm{H}_{2} \mathrm{P}^{2+}-\mathrm{H}_{2} \mathrm{P}^{+\cdot}$ and $\mathrm{H}_{2} \mathrm{P}^{2+}$ $\mathrm{H}_{2} \mathrm{P}^{2+}$ species indicating that after the first ring oxidation, the porphyrin rings become distinct leading to discrete steps for the second ring oxidation. (table 1) the first and second ring reduction processes of the free-base bisporphyrins, however, occur in single steps involving two electrons with the possible existence of $\mathrm{H}_{2} \mathrm{P}^{--}-\mathrm{H}_{2} \mathrm{P}^{-}$and $\mathrm{H}_{2} \mathrm{P}^{2--}-\mathrm{H}_{2} \mathrm{P}^{2-}$ respectively. This suggests that the reduction steps do not distinguish of the porphyrin rings. The ring oxidation and reduction for zinc(II) derivatives of the bisporphyrins appear as broad peaks and involve twoelectron processes. This is unlike those reported for 
bisporphyrins containing variable length of covalent linkages. ${ }^{19}$ A possible reason for this lies in the marginally longer distance between the two porphyrin
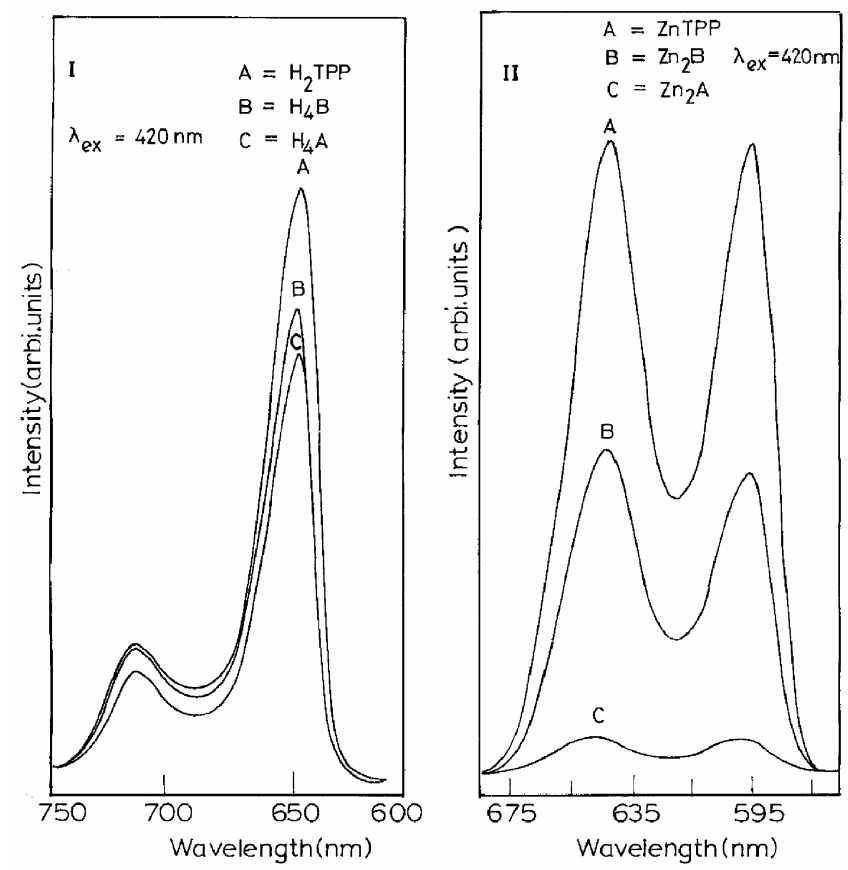

Figure 5. Fluorescence spectra of $\mathrm{I}, \mathrm{H}_{4} \mathrm{~A}$ and $\mathrm{H}_{4} \mathrm{~B}$, and II, $\mathrm{Zn}_{2} \mathrm{~A}$ and $\mathrm{Zn}_{2} \mathrm{~B}$ bisporphyrins in dichloroethane at $298 \mathrm{~K}$. Excitation at $420 \mathrm{~nm}$.

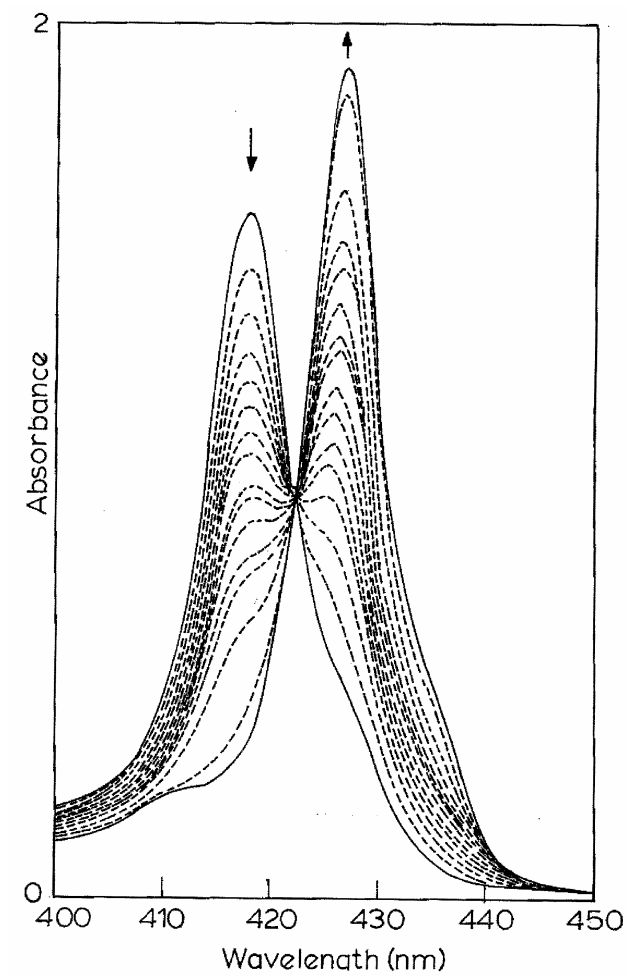

Figure 6. Optical absorption spectra of $Z \mathrm{n}_{2} \mathrm{~A}$ in dichloroethane on successive addition of PMDA at $298 \mathrm{~K}$. rings in the metallated derivatives. The second ring reduction occurs at a potential too close to the solvent reduction and hence is not observed. The observation of successive one-electron ring oxidation in the free-base porphyrin, $\mathrm{H}_{4} \mathrm{~A}$ suggests that the nature of the pre-oxidised species at the electrode surface is quite different from those of zinc(II) derivative.

\section{Axial ligation studies}

The absorption spectra of $\mathrm{Zn}_{2} \mathrm{~A}$ on increasing concentration of PMDA are shown in figure 6. The Soret band of the free host is shifted from $415 \mathrm{~nm}$ to $424 \mathrm{~nm}$ and the visible band at $548 \mathrm{~nm}$ is shifted to $563 \mathrm{~nm}$ in the complex. The progressive decrease in

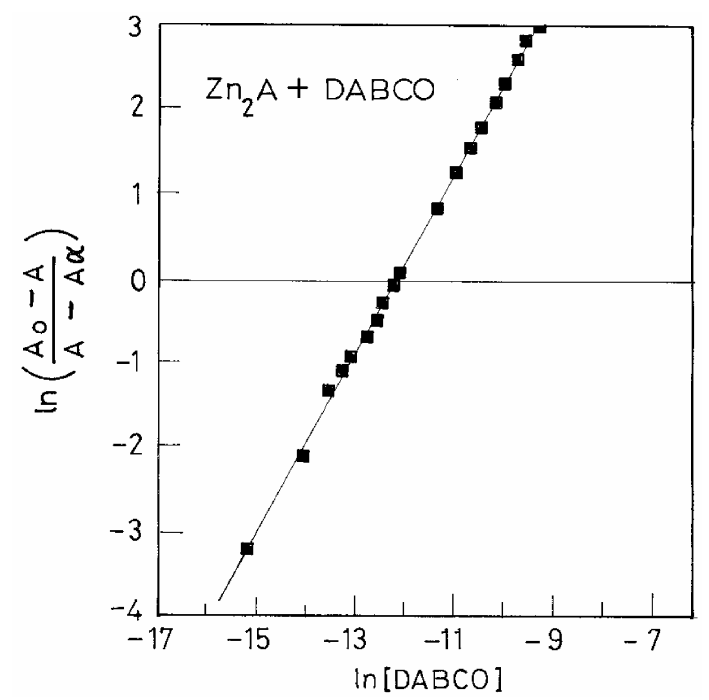

Figure 7. Hill plot of $\mathrm{Zn}_{2} \mathrm{~A}$ complexation with DABCO.

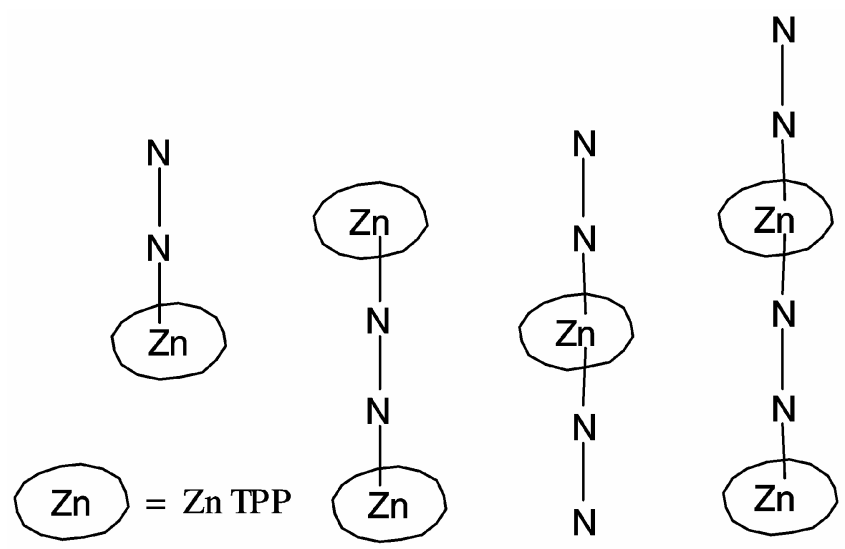

Figure 8. Different possible binding modes of ZnTPP with a bidentate ligand, $\mathrm{DABCO}$. 
intensity of absorption bands of the free host, $\mathrm{Zn}$ (II) bisporphyrin and increase in intensity of bands corresponding to the complex are monitored as a function of increasing concentration of the bases. The $\mathrm{UV}$-visible spectral changes upon addition of $\mathrm{DABCO} /$ PMDA to dichloroethane solution of $\mathrm{Zn}_{2} \mathrm{~A} / \mathrm{Zn}_{2} \mathrm{~B}$ showed isobestic points. A representative Hill plot of In $\left(A_{o}-A\right) /\left(A-A_{\infty}\right)$ vs $\ln [\mathrm{DABCO}]$, where $A_{o}$ and $A_{\infty}$ are the absorbance values at $415 \mathrm{~nm}$ of free zinc(II) bisporphyrin and in presence of added base

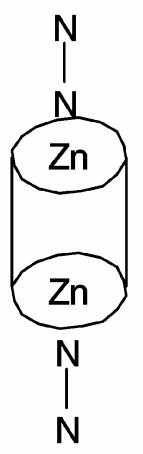

Cofacial dimer

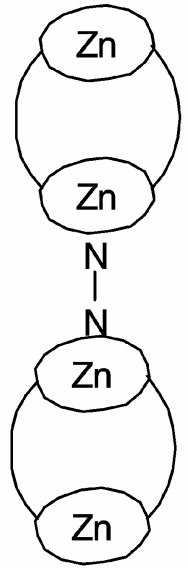

Ternary

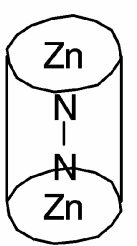

Sandwich
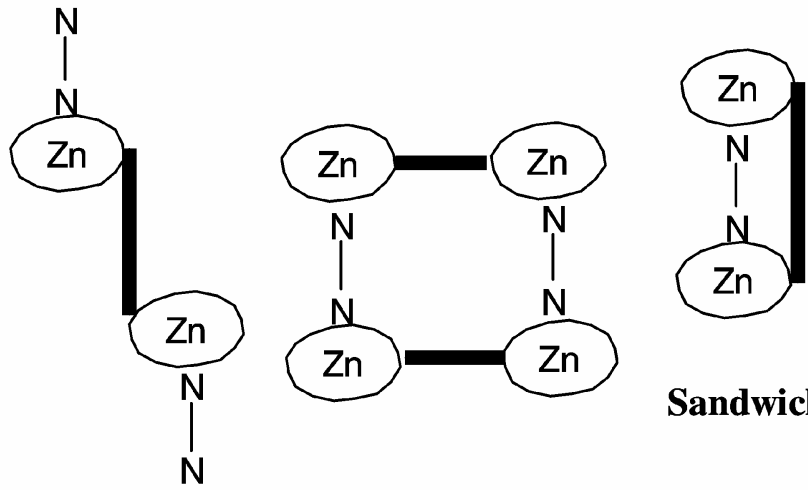

Sandwich

Figure 9. Different modes of binding of $\mathrm{Zn}(\mathrm{II})$ bisporphyrins with DABCO.

Table 2. Binding Constants for the axial ligation of bases with Bisporphyrins in $\mathrm{C}_{2} \mathrm{H}_{4} \mathrm{Cl}_{2}$ at $298 \mathrm{~K}$.

\begin{tabular}{lcc}
\hline & \multicolumn{2}{c}{$\log K$} \\
\cline { 2 - 3 } Porphyrin & $\mathrm{DABCO}$ & PMDA \\
\hline ZnTPP & $5 \cdot 76$ & 4.62 \\
$m$-cis- $\mathrm{Zn}_{2} \mathrm{~B}$ & $6 \cdot 70$ & $6 \cdot 25$ \\
$m$-cis- $Z \mathrm{n}_{2} \mathrm{~B}$ & $8 \cdot 30$ & $8 \cdot 15$ \\
\hline
\end{tabular}

The uncertainity in the values are $\pm 7 \%$

respectively, and $\mathrm{A}$ is the absorption value of the complex is displayed in figure 7 . The linearity of the
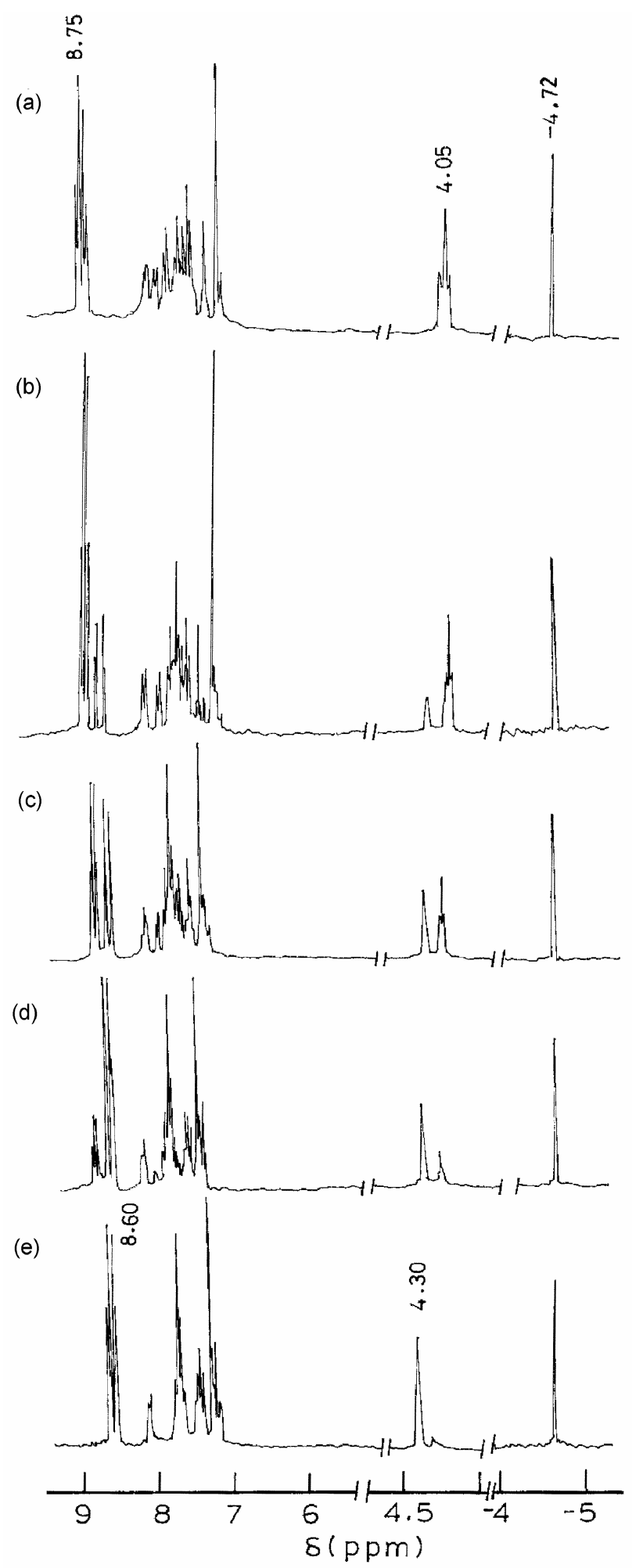

Figure I0. ${ }^{1} \mathrm{H}$ NMR spectra of $\mathrm{CDCl}_{3}$ solutions containing different mole ratios of $\mathrm{Zn}_{2} \mathrm{~A}$ and $\mathrm{DABCO}$. The molar ratio of $\mathrm{Zn}_{2} \mathrm{~A}$ to $\mathrm{DABCO}$ in different spectra are (a) $1: 0 \cdot 10$; (b) $1: 0 \cdot 30$; (c) $1: 0 \cdot 50$; (d) $1: 0 \cdot 70$; (e) $1: 1$. 
plot with a slope of near unity indicates that the predominant species existing in solution is of $1: 1$ stoichiometry $\left(\mathrm{Zn}_{2} \mathrm{P}: \mathrm{L}-\mathrm{L}\right)$. The equilibrium constant, $\mathrm{K}$ values were evaluated from the intercepts of
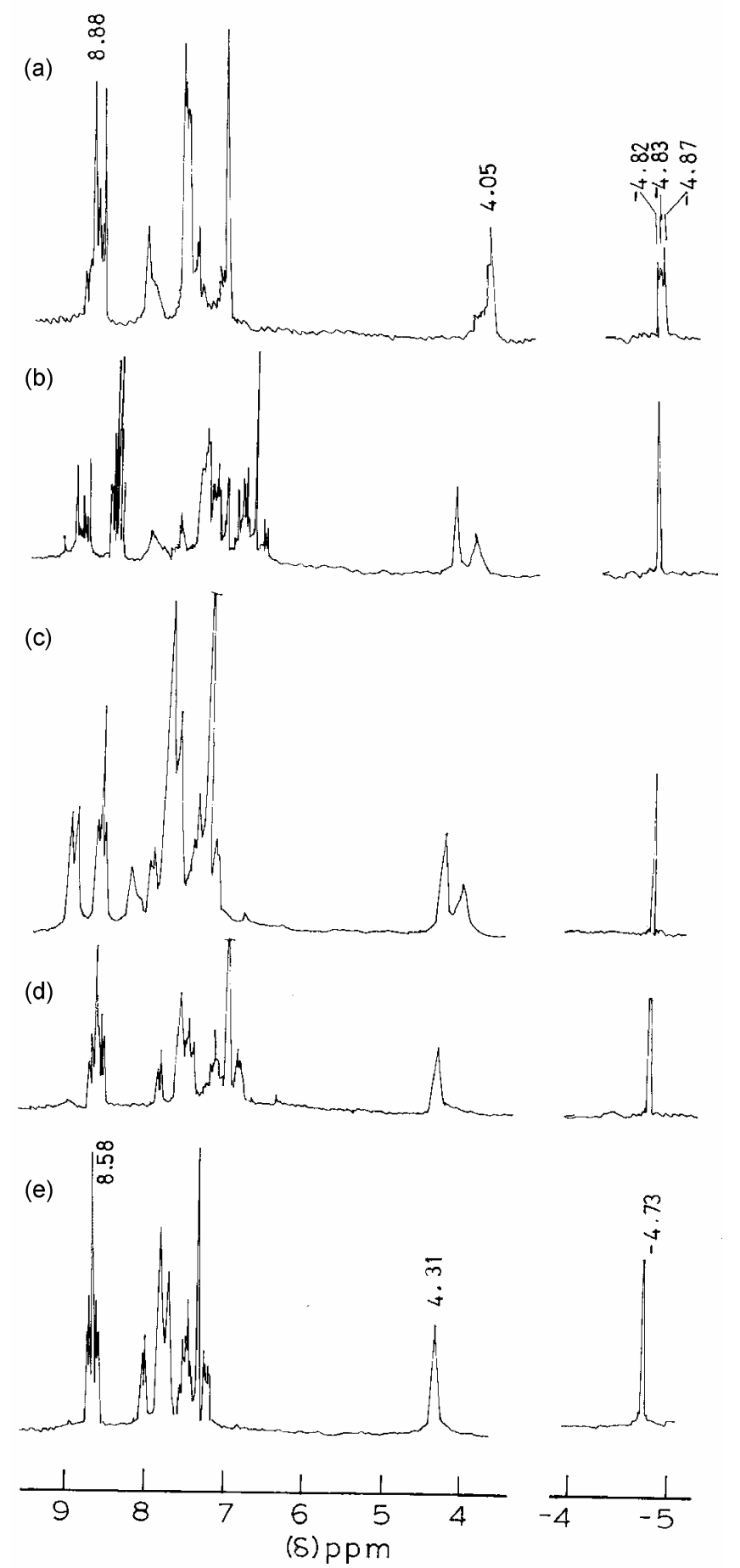

Figure 11. ${ }^{1} \mathrm{H}$ NMR spectra of $\mathrm{CDCl}_{3}$ solutions containing different mole ratios of $\mathrm{Zn}_{2} \mathrm{~B}$ and $\mathrm{DABCO}$. The molar ratio of $\mathrm{Zn}_{2} \mathrm{~B}$ to $\mathrm{DABCO}$ in different spectra are: (a) $1: 0 \cdot 10$; (b) $1: 0 \cdot 30 ;$ (c), $1: 0 \cdot 50$; (d) $1: 0 \cdot 70$; (e) $1: 1$. the respective Hill plots. The values of $\mathrm{K}$ determined from the increase in absorbance at $424 \mathrm{~nm}$ is similar in magnitude to that found by analysing decrease in the absorbance changes at $415 \mathrm{~nm}$.

It is found useful to compare the magnitude of $\mathrm{K}$ values obtained for base binding to bisporphyrins with those of monomeric ZnTPP. Experiments were performed under similar conditions to investigate the equilibria of ZnTPP complexation with PMDA/ DABCO. The binding curve for the titration of DABCO/PMDA with ZnTPP showed the formation of $1: 1$ complex. The equilibrium constants for the zinc(II) bisporphyrins with bases are given in table 2 along with the ZnTPP complexation data. The $\mathrm{K}$ value for binding of $\mathrm{Zn}$ (II) bisporphyrins with $\mathrm{DABCO}$ and PMDA are significantly higher than those observed for monomeric ZnTPP and similar in magnitude to those reported earlier. ${ }^{13}$ It is of interest to note that the bisporphyrin, $\mathrm{Zn}_{2} \mathrm{~B}$ exhibits $1: 1 \mathrm{com}$ plexation with $\mathrm{DABCO}$ and PMDA displaying lower $\mathrm{K}$ values relative of $\mathrm{Zn}_{2} \mathrm{~A}-\mathrm{DABCO} / \mathrm{PMDA}$. A possible reason for this lies in the closed conformation associated with the $\mathrm{Zn}_{2} \mathrm{~A}$, where the pre-organisation of the host molecule to accommodate a guest molecule is already built-in. In addition, the presence of a rigid bridge between the two binding sites favours complexation to geometrically well defined bidentate ligand. Among the two bidentate ligands, larger $\mathrm{K}$ values are observed for binding of DABCO to bisporphyrins relative to the binding of PMDA. This is understandable due to higher chelating factor of DABCO relative to PMDA. ${ }^{20}$

The complexation of bidentate ligands to zinc(II) derivatives of the bisporphyrins is followed by ${ }^{1} \mathrm{H}$ NMR studies. The proton resonance feature of DABCO binding to monoZinc(II) porphyrin, ZnTPP provide a useful approach towards understanding the nature and mode of binding of the ligand to bismetal porphyrins. The methylene proton resonances of DABCO resonate as a singlet at $2.27 \mathrm{ppm}$ in $\mathrm{CDCl}_{3}$. Addition of this ligand $(0.5$ mole $)$ to 1.0 mole of ZnTPP shifts the resonances of methylene protons to $-4.75 \mathrm{ppm}$. Increasing addition $(1.0 \mathrm{~mole})$ of DABCO to ZnTPP (1.0 mole) results in the shift of methylene protons to $-1.03 \mathrm{ppm}$ and any further addition of the ligand does not result in any significant shift of these proton resonances. These observations are interpreted in terms of different modes of binding of bidentate ligand to ZnTPP (figure 8) which can be visualised as follows: a binary complex in which only one donor nitrogen of $\mathrm{DABCO}$ is coor- 
Table 3. Selected bond lengths $(\AA)$ and angles for $\mathrm{Zn}_{2} \mathrm{~A} \cdot \mathrm{DABCO} .8 \mathrm{C}_{2} \mathrm{H}_{4} \mathrm{Cl}_{2}$. $\mathrm{H}_{2} \mathrm{O}$ with esd's in parentheses*.

\begin{tabular}{llll}
\hline Zn1-N1 & $2 \cdot 085(10)$ & C3-C4 & $1 \cdot 476(21)$ \\
Zn1-N2 & $2 \cdot 069(7)$ & C4-C5 & $1 \cdot 411(17)$ \\
Zn1-N3 & $2 \cdot 112(9)$ & C5-C6 & $1 \cdot 530(19)$ \\
Zn1-N4 & $2 \cdot 085(7)$ & N1-C1 & $1 \cdot 397(15)$ \\
Zn1-N5 & $2 \cdot 222(7)$ & N1-C4 & $1 \cdot 407(15)$ \\
C1-C2 & $1 \cdot 449(22)$ & C2-C3 & $1 \cdot 368(17)$ \\
NS-C50 & $1 \cdot 488(26)$ & N5-C51 & $1 \cdot 445(25)$ \\
N5-C52 & $1 \cdot 637(33)$ & O1-C19 & $1 \cdot 376(15)$ \\
02-C41 & $1 \cdot 327(13)$ & O2-C45 & $1 \cdot 449(15)$ \\
C45-C46 & $1 \cdot 501(18)$ & C46-C47 & $1 \cdot 495(18)$ \\
C47-C48 & $1 \cdot 545(18)$ & C48-C49 & $1 \cdot 488(18)$ \\
N4-Zn1-N5 & $99 \cdot 8(3)$ & C1-N1-C4 & $105 \cdot 0(9)$ \\
N3-Zn1-N4 & $87 \cdot 5(3)$ & O2-C41-C42 & $126(1)$ \\
N2-Zn1-N4 & $160 \cdot 2(3)$ & O2-C45-C46 & $108 \cdot 5(9)$ \\
Zn1-N1-C1 & $127 \cdot 4(7)$ & N1-C1-C2 & $110(1)$ \\
Zn1-N2-C12 & $125 \cdot 9(7)$ & C1-C2-C3 & $109(1)$ \\
Zn1-N5-C52 & $109(1)$ & C45-C46-C47 & $115(1)$ \\
C46-C47-C48 & $114(1)$ & C47-C48-C49 & $114(1)$ \\
\hline
\end{tabular}

*Ref. 28

dinated to $\mathrm{Zn}(\mathrm{II})$ while the other nitrogen remain unbound. Alternately, the two donor sites (of DABCO) situated opposite to one another can bind two $\mathrm{Zn}(\mathrm{II})$ centers independently resulting in a ternary complex. ${ }^{2 a}$ It is possible to conceive hexa coordinated $\mathrm{Zn}$ (II) ion in which case a coordinated aggregate and/or a mixture of five and six coordinated structure can result. The optical absorption data clearly indicates the existence of five coordinated zinc(II) and hence we limit our discussion only to five coordinated species. It is found that at low concentration of $\mathrm{DABCO}$, the methylene protons are considerably shielded (by $8.00 \mathrm{ppm}$ ) indicating that the ligand protons are restricted in space and come under the influence of strong ring current effect imposed by the donor porphyrins. This situation is well-represented in the ternary structure. Increasing addition of DABCO to ZnTPP (1:1 mole) reduces the magnitude of the shift of methylene proton resonances to $3.30 \mathrm{ppm}$ suggesting that the ring current effect experienced by these protons is diminished. This is consistent with that of a binary complex wherein only one porphyrin unit is involved in causing the ring current shift of the resonances. This suggests that the magnitude of the shift of ligand proton resonances provide information on the modes of coordination of DABCO to zinc(II) porphyrins. We shall return to our study on the complexation of DABCO with two $\mathrm{Zn}(\mathrm{II})$ derivatives of the bisporphyrins. The conceivable modes of coordination is depicted in figure 9 . The spectral changes brought about by complexation of $\mathrm{DABCO}$ with $\mathrm{Zn}_{2} \mathrm{~A} / \mathrm{Zn}_{2} \mathrm{~B}$ are displayed in the figures 10 and 11 respectively. Initial addition of 0.3 mole of DABCO to one mole of the zinc(II) bisporphyrins results in the existence of proton resonances that can be ascribed to both the complexed DABCO species and uncomplexed bisporphyrins. This is due to the slow exchange between the free host and complexed species as revealed by large equilibrium constant $(\log K \sim 8.20)$ determined by optical absorption method. Increasing addition of $\mathrm{DABCO}$, up to 1.0 mole, results in the slow disappearance of the proton resonances of uncomplexed bisporphyrins with the predominant existence of the complexed species. Addition of DABCO beyond 1.0 mole results in the appearance of protons resonances of free $\mathrm{DABCO}$ at $2.27 \mathrm{ppm}$ and bound $\mathrm{DABCO}$ at $-4.75 \mathrm{ppm}$, indicating fast exchange between bound and free DABCO in solution.

It is of interest to note that in solutions containing [DABCO] $<\mathrm{Zn}_{2} \mathrm{~A} / \mathrm{Zn}_{2} \mathrm{~B}$, the methylene proton resonances of $\mathrm{DABCO}$ appear as a singlet at $-4.72 \mathrm{ppm}$ in the case of $\mathrm{Zn}_{2} \mathrm{~A}$ complexation (figure 10) and three singlets at $-4.82,-4.83$ and $-4.87 \mathrm{ppm}$ for $\mathrm{Zn}_{2} \mathrm{~B}$ complexation (figure 11). The existence of single resonance for the ligand protons in the complexation with $\mathrm{Zn}_{2} \mathrm{~A}$ indicates the formation of an unique complex while the appearance of multiple resonances of $\mathrm{DABCO}$ in $\mathrm{Zn}_{2} \mathrm{~B}$ complexation is possibly related to the coexistence of different complexes of varying structures. The large magnitude of shielding $(\sim 8.00$ $\mathrm{ppm}$ ) experienced by the methylene protons of 
DABCO in $\mathrm{Zn}_{2} \mathrm{~A}$ complex suggests that these protons are situated well within the strong ring current zone of the two porphyrin units consistent with the sandwich structure. We attribute the resonances at $4.87,-4.83$ and $-4.82 \mathrm{ppm}$ to ternary, sandwich and binary complexes respectively. It is worthy to mention here that $Z_{2} B$, unlike $Z_{2} A$ can exist in different conformations and hence the approach of DABCO towards the $\mathrm{Zn}(\mathrm{II})$ ions of bisporphyrin varies considerably resulting in different structures. It is important to observe that the resonance of methylene protons of DABCO remain unshifted $(-4.72 \mathrm{ppm})$ despite increasing the ratio of the ligand to $\mathrm{Zn}_{2} \mathrm{~A}$. However, under the same conditions, the three distinct resonances of $\mathrm{DABCO}$ bound to $\mathrm{Zn}_{2} \mathrm{~B}$ are collapsed to a single resonance at $-4.73 \mathrm{ppm}$. This indicates the different modes of binding of the ligand in $\mathrm{Zn}_{2} \mathrm{~B}-\mathrm{DABCO}$ complex existing at low concentration of the ligand are transformed to the sandwich structure at higher concentration. The conformational changes of $\mathrm{Zn}_{2} \mathrm{~A} / \mathrm{Zn}_{2} \mathrm{~B}$ during complexation with DABCO are discernible in the shifts of resonances of bridging $-\mathrm{OCH}_{2}$ - protons of the hosts, pyrrole protons and meso phenyl groups. The upfield shift $(\sim 0.30 \mathrm{ppm})$ of the $-\mathrm{OCH}_{2}$-protons and

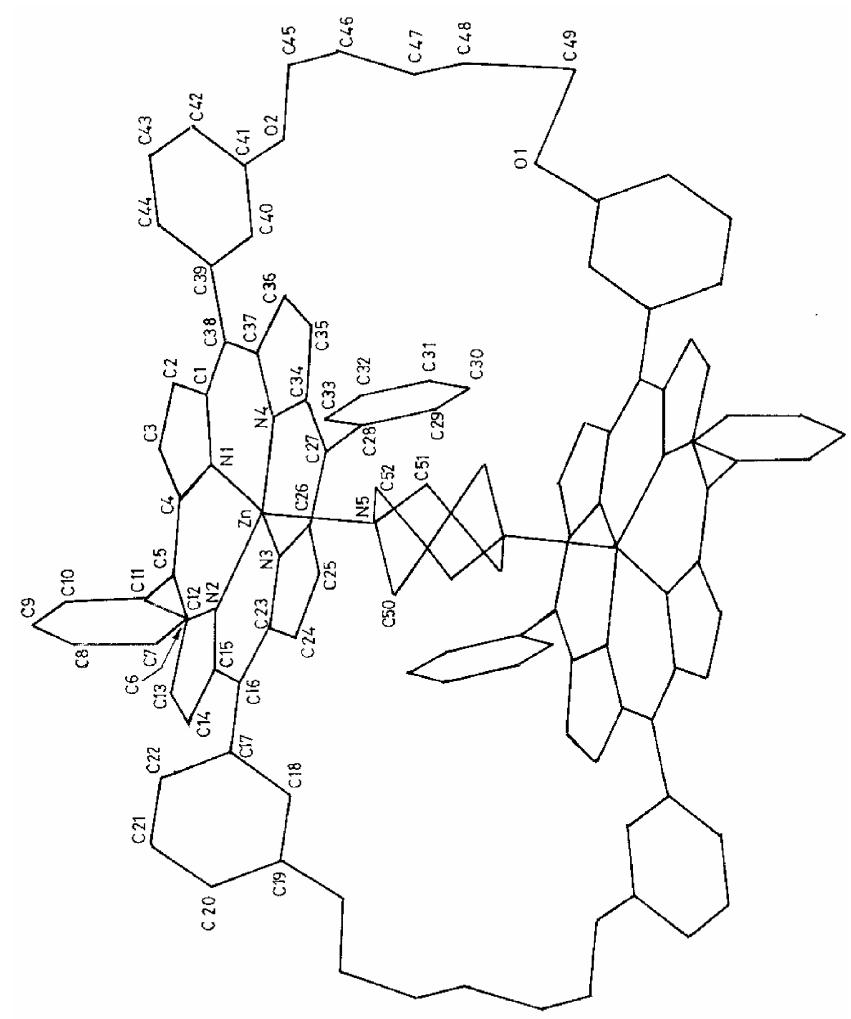

Figure 12. Atomic numbering scheme for the $\mathrm{Zn}_{2} \mathrm{~A}$. DABCO complex. The carbon atoms of solvent molecules are not shown. the complex multiplet resonance of meso-aryl protons indicate the skeletal motions of these groups as the ligand being coordinated to the $\mathrm{Zn}(\mathrm{II})$ ions. The pyrrole proton resonances of $\mathrm{Zn}_{2} \mathrm{~A}$ appear as two doublets during complexation with a marginal upfield shift of $0.15 \mathrm{ppm}$. However, there is a large change in the multiplet structure of the pyrrole proton resonances of $\mathrm{Zn}_{2} \mathrm{~B}$ resulting in two doublets and two singlets accompanied by an upfield shift of $0.34 \mathrm{ppm}$. This observation signifies sandwich structure of the complex with two porphyrin planes facing one another and DABCO interposed between the planes. A possible reason for the absence of large segmental motion of the groups in $\mathrm{Zn}_{2} \mathrm{~A}$ on complexation with $\mathrm{DABCO}$ is related to the pre-existent conformation readily available for coordination.

Interesting results have been obtained on PMDA complexation with the bisporphyrins. The free PMDA in $\mathrm{CDCl}_{3}$ exhibit resonances at $1.02(s), 2.54$ $(t)$ and $1.24(\mathrm{~m}) \mathrm{ppm}$ corresponding to the protons of $-\mathrm{NH}_{2},-\mathrm{CH}_{2} \mathrm{NH}_{2}$ and $-\left(\mathrm{CH}_{2}\right)_{3}$-groups, respectively. These resonances are shifted upfield on coordination of PMDA to the two $\mathrm{Zn}$ (II) ions of the bisporphyrins. At low concentration (ratio of PMDA/ $\mathrm{Zn}_{2} \mathrm{~A}=0.5$ ), the proton resonances of PMDA appear at $-5.24 \mathrm{ppm},-3.04 \mathrm{ppm}$ and at $-2.39 \mathrm{ppm}$ corresponding to $-\mathrm{NH}_{2},-\mathrm{CH}_{2} \mathrm{NH}_{2}$ and $-\left(\mathrm{CH}_{2}\right)_{3}$ groups, respectively, while for $\mathrm{Zn}_{2} \mathrm{~B}$ complexation the corresponding proton resonances occur at -5.08 , 2.96 and $-2.29 \mathrm{ppm}$. The large magnitude of the upfield shift of the proton resonances along with the loss in the multiplet structure (relative to the resonances of free ligand arise from the ring current effect induced by the two porphyrin units of the bisporphyrins. Two effects come into operation on increasing the ratio of (PMDA/ $\left.\left(\mathrm{Zn}_{2} \mathrm{~A} / \mathrm{Zn}_{2}\right)\right)$ beyond $0 \cdot 5$. Firstly, the line width of the proton resonances of the ligand increases and the broadening of the resonances is relatively higher for $Z_{2} B$ than that observed for $\mathrm{Zn}_{2} \mathrm{~A}$. Secondly, the proton resonances of the unbound PMDA start appearing at $2.63 \mathrm{ppm}$. These observations suggest that there is a fast exchange of proton resonances between the unbound and bound PMDA. The proton resonances of the host entities $\mathrm{Zn}_{2} \mathrm{~A} / \mathrm{Zn}_{2} \mathrm{~B}\left(\mathrm{H} / / \mathrm{OCH}_{2}\right)$ show only marginal downfield shift on complexation with PMDA.

\subsection{Crystal structure of $\mathrm{Zn}_{2} A \cdot D A B C O$ complex}

The host-guest complex $\mathrm{Zn}_{2} \mathrm{~A} \cdot \mathrm{DABCO} .8 \mathrm{C}_{2} \mathrm{H}_{4} \mathrm{Cl}_{2}$. $\mathrm{H}_{2} \mathrm{O}$ was crystallized in the monoclinic system with 
two molecules in the unit cell. The selected bond lengths and angles of the porphyrin skeleton including the axially co-ordinated ligand molecule are given in table 3 . Figure 12 depicts the atom numbering scheme, and an ORTEP diagram is shown in figure $13 .{ }^{28}$ All the atoms in the $\mathrm{Zn}$ (II) porphyrin skeleton are well-defined with no significant differences in bond length and bond angles and are similar to monomeric ZnTPP-base crystal structures. ${ }^{21}$ The

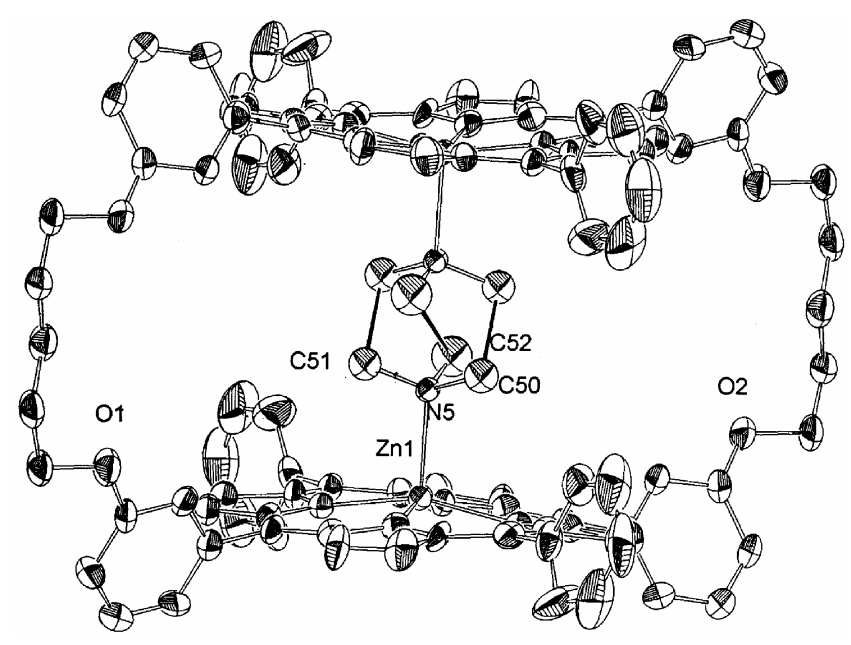

Figure 13. An ORTEP diagram of $\mathrm{Zn}_{2} \mathrm{~A} \cdot \mathrm{DABCO}$ complex with thermal ellipsoids showing $30 \%$ probability.

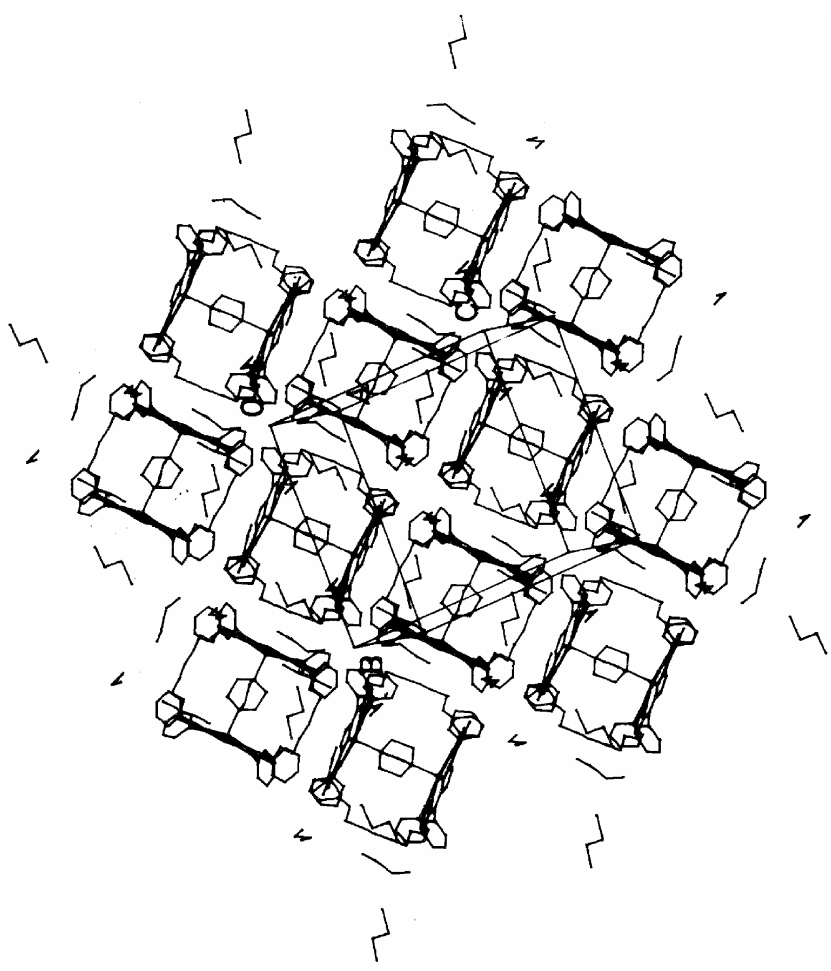

Figure 14. Crystal packing of $\mathrm{Zn}_{2} \mathrm{~A} \cdot \mathrm{DABCO}$ complex. structure has $\mathrm{DABCO}$ encapsulated $\mathrm{Zn}_{2} \mathrm{~A}$ complex with eight dichloroethane and a water molecule. The molecule indeed accommodates the guest, the central point of which describes a crystallographically imposed center of inversion. DABCO is coordinatively bonded to both $\mathrm{Zn}$ atoms of the bisporphyrins. The average $\mathrm{Zn}-\mathrm{N}$ distances (in the zinc porphyrin) for the complex are 2.08 and 2.22 A and are similar to those found for a number of axially nitrogen base coordinated $\mathrm{Zn}(\mathrm{II})$ porphyrins. ${ }^{21}$ The $\mathrm{Zn}$ atom is pulled into the cavity by the nitrogens of DABCO and they are deviating from the mean plane (formed by four pyrrolic nitrogens, N4 plane) by about $0.35 \AA$. Average distance between the $\mathrm{Zn}-\mathrm{N}$ (of the $\mathrm{DABCO}$ ) is found to be $2.22 \AA$. It can be seen from the ORTEP diagram that DABCO is positionally disordered and the bond distances significantly differs from their normal values. The alkyl linkers are $\sim 20 \AA$ away from each other (figure 13) allowing the molecule to have a large cavity inside the molecule, part of which is filled by DABCO and other solvent molecules. The rest of the cavity assumes a triangular sheet like hole around the DABCO (void volume $\sim 450 \AA^{3}$ ). The two alkyl linkers, the midpoint of which defines a virtual two fold axis through the center of DABCO are covalently bonded to the trans-meta-hydroxy group of the meso-phenyl rings and are essentially planar with the maximum mean plane deviation being $0.08 \AA$. These bridging groups are parallel to each other and perpendicular to the porphyrin plane. All the carbon atoms of the alkyl group are well ordered and have staggered conformation instead of the more stable gauche conformation. This could be related to the moderately strong hydrogen bonding with the porphyrin ring of a nearest neighbour (figure 14). The porphyrin ring is found to be nonplanar. The alternate pyrrole rings are rotated either clockwise or anticlockwise around the $\mathrm{Zn}-\mathrm{N}$ bonds such that the meso-carbons are above and below the mean plane alternatively. The mean deviation of the meso-carbon atoms are $0 \cdot 16$, $0.12,0.18$ and $-0.13 \AA$. A parallel arrangement of the mean planes of the porphyrins is observed and is separated by a distance of $7 \AA$. The observed ruffled conformation of the porphyrin rings in the structure is possibly due to the steric constraints imposed by the meso-phenyl substituents or intermolecular interactions with the neighbouring molecules in the lattice. Bisporphyrins without self-complementary shapes does not stablilize the host lattice structure without the incorporation of solvent molecules. So is 
the case in this system, where the lattice structure gets stabilized by incorporation of dichloroethane and water molecules in the lattice. In porphyrin sponges, it has been reported that the host lattices have a sheet like cavity through out the lattice which is having $\pi$-stacking origin. ${ }^{22}$ The present structure does not have sheet like channels, and the complementary voids are occupied by the solvent molecules. Majority of the bisporphyrin complexes tend to adopt an offset orientation to minimize $\pi-\pi$ repulsion and maximize $\sigma-\pi$ attraction. ${ }^{23}$ The present structure shows perfect face-to-face stacking of the two $\mathrm{Zn}(\mathrm{II})$ porphyrins in an eclipsed configuration with nearly zero offset geometry. No screwed down conformation has been observed between the two porphyrin rings. Another striking feature is that the slippage or lateral displacement of the two $\mathrm{Zn}$ atoms are close to zero. This is possibly due to binding of DABCO and outward stretching of the alkyl linkers brings the rings closer to each other thereby increasing $\pi-\pi$ interaction.

\section{Acknowledgements}

The authors are thankful to the Department of Science and Technology (DST), Government of India for the support. The authors (G V) and (S K M) thank the Jawaharlal Nehru Centre for Advanced Scientific Research, Bangalore for the financial support.

\section{References}

1. (a) Collman P, Wagenknecht P S and Hutchison J E 1994 Angew. Chem. Int. Ed. Engl. 33 1537; (b) Nam W, Han H J, Oh S-Y, Lee Y J, Choi M-H, Han S-Y, Kim C, Woo S K and Shin W $2000 \mathrm{~J}$. Am. Chem. Soc. 1228677

2. (a) Otsuka S and Yamanaka T (eds) 1988 Metalloproteins: Chemical properties and biological effects (Amsterdam: Elsevier); (b) Ravikanth $\mathrm{M}$ and Chandrashekar T K 1995 Structure and Bonding 82 105

3. (a) Heiler D, McLendon G and Rogalskyj P $1987 \mathrm{~J}$. Am. Chem. Soc. 109 604; (b) Tabushi I and Kugimiya S 1986 J. Am. Chem. Soc. 108 6926; (c) Sessler J L, Johnson M R, Lin T-Y and Creager S E $1988 \mathrm{~J}$. Am. Chem. Soc. 1103659

4. (a) Jeyakumar D and Krishnan V 1992 Spectrochimica Acta A48 1671; (b) Tian H-J, Zhou Q-F, Shen S-Y and Xu H-J 1993 J. Photochem. Photobiol. A: Chem. 163

5. (a) Anderson H L, Hunter C A, Meah M N and Sanders J K M $1990 \mathrm{~J}$. Am. Chem. Soc. 1125780 and ref- erences therein; (b) Danks I P, Lane T G, Sutherland I O and Yep M 1992 Tetrahedron 42 7699; (c) Collman J P, Tyvoll D A, Chang L L and Fish H T 1995 J. Org. Chem. 601926

6. Chang K, Liu H Y and Abdalmuhdi I $1984 \mathrm{~J}$. Am. Chem. Soc. 1062725

7. Leighton, Cowan J A, Abraham and R J and Sanders J K M 1988 J. Org. Chem. 53733

8. Collman P, Denisevich P, Konai Y, Marrocco M, Koval C and Anson F C $1980 \mathrm{~J}$. Chem. Soc. Chem. Commun. 6027

9. (a) Collman J P, Anson F C, Bencosme S, Chong A, Collins Y, Denisevich P, Evitt E, Geiger T, Ibers J A, Jameson G, Konai Y, Koval C, Meier K, Oakley P, Pettman R, Schmittou E and Sessler J 1981 Organic Synthesis: Today and tomorrow (eds) B M Trost and C R Hutchinson (Oxford: Pergaman Press) 29; (b) Collman J P, Elliot C M, Halbert T R and Tovrog B S 1977 Proc. Natl. Acad Sci. USA 7418

10. (a) Kagan E, Mauzerall D and Merrifield R B 1977 J. Am. Chem. Soc. 99 5484; (b) Kagan N E 1979 Porphyrin chemistry advances (ed.) F R Longo Ann. Arbor. Sci. 43

11. Karaman, Blasko A, Almarsson O, Arasasingam R and Bruice T C 1992 J. Am. Chem. Soc. 1144889

12. (a) Landrum, Reed C A, Hatano K and Scheidt W R 1978 J. Am. Chem. Soc. 100 3232; (b) Neumann K H and Vogle F $1988 \mathrm{~J}$. Chem. Soc. Chem. Commun. 520; (c) Golubchikov O A, Korovina S G, Kuvshinova E M, Semeikin A S, Shul'ga A M, Perfil'ev V A, Syrbu S A and Berezin B D $1989 \mathrm{~J}$. Org. Chem. USSR (Engl. Transl.) 2144

13. (a) Hunter A, Meah M N and Sanders J K M $1990 \mathrm{~J}$. Am. Chem. Soc. 12 5773; (b) Anderson H L, Bashall A, Henrick K, McPartlin M and Sanders J K M 1994 Angew. Chem. 33 429; (c) Uemori Y, Nakatsubo A, Imai H, Nakagawa S and Kyuno E 1992 Inorg. Chem. 31 5164; (d) Imai H and Uemori Y 1994 J. Chem. Soc. Perkin Trans. 2 1793; (e) Anderson H L and Sanders J K M 1995 J. Chem. Soc. Perkin Trans 1, 2223; (f) Anderson H L, Anderson S and Sanders J K M 1995 ibid 2231; (g) Anderson S, Anderson H L and Sanders J K M 1995 ibid 2247 and 2256; (h) Mackay L G, Anderson H L and Sanders J K M 1995 ibid 2269; (i) Wylie R S, Levy E G and Sanders J K M 1997 Chem. Commun. 1611

14. (a) Chang, Kuo M-S and Wang C-B 1977 J. Heterocycl. Chem. 14 943; (b) Chang C K 1977 J. Heterocycl. Chem. 14 1285; (c) Collman J P, Bencosme C S, Barnes C E and Miller B D $1983 \mathrm{~J}$. Am. Chem. Soc. 105 2704; (d) Collman J P, Denisevich P, Konai Y, Marrocco M, Koval and Anson F C $1980 \mathrm{~J}$. Am. Chem. Soc. 102 6027; (e) Karaman R, Jeon S, AImarsson O and Bruice T C $1992 \mathrm{~J}$. Am. Chem. Soc. 1144899

15. Crossley, Harding M M and Sternhell S 1992 J. Org. Chem. 571833

16. Sun, Martell A E and Tsutsui M 1986 J. Heterocycl. Chem. 23561

17. (a) Walter I, Ojadi E C A and Linschitz H $1993 \mathrm{~J}$. Phys. Chem. 97 13308; (b) Ojadi E C A, Linschitz H, 
Gouterman M, Walter R I, Lindsey J S, Wagner R W, Droupadi P R and Wang W 1993 J. Phys. Chem. 97 13192

18. Hunter, Leighton P and Sanders J K M 1989 J. Chem. Soc. Perkin Trans. 1547

19. Mest, L'Her M, Hendricks N H, Kim K and Collman J P 1992 Inorg. Chem. 31835

20. Danks, Sutherland I O and Yap C H 1990 J. Chem. Soc. Perkin Trans. 1421

21. (a) Fleischer C K, Miller L E and Webb $1964 \mathrm{~J}$. Am. Chem. Soc. 86 2342; (b) Glick M D, Cohen G H and Hoard J L1967 J. Am. Chem. Soc. 89 1996; (c) Scheidt W R, Kastner M E and Hatano K 1978 Inorg. Chem. 17 706; (d) Hatana K, Kawasaki K, Munakata S and Iitaka Y 1987 Bull. Chem. Soc. Jpn. 601985
22. Bym, Curtis C J, Goldberg I, Hsiou Y, Khan S I, Sawin P A, Tendick S K and Strouse C E $1991 \mathrm{~J}$. Am. Chem. Soc. 1136549

23. Hunter and Sanders J K M 1991 J. Am. Chem. Soc. 1125525

24. Bhyrappa P and Krishnan V 1991 Inorg. Chem. 30239

25. Hill 1910 Physiol. London 40 IV-VII

26. Sheldrick 1986 SHELXS-86 Program for crystal structure determination, University of Gottingen, Republic of Germany

27. Sheldrick 1976 SHELXS-76 Program for crystal structure determination, University of Cambridge, UK

28. Vaijayanthimala G $1996 \mathrm{PhD}$ thesis, see details for figures 12-13, Indian Institute of Science, Bangalore, India 